\title{
$\mathrm{ADB}$
}

STRATEGI2030

Mencapai Asia dan Pasifik yang Makmur, Inklusif,

Tangguh, dan Berkelanjutan

JULI 2018

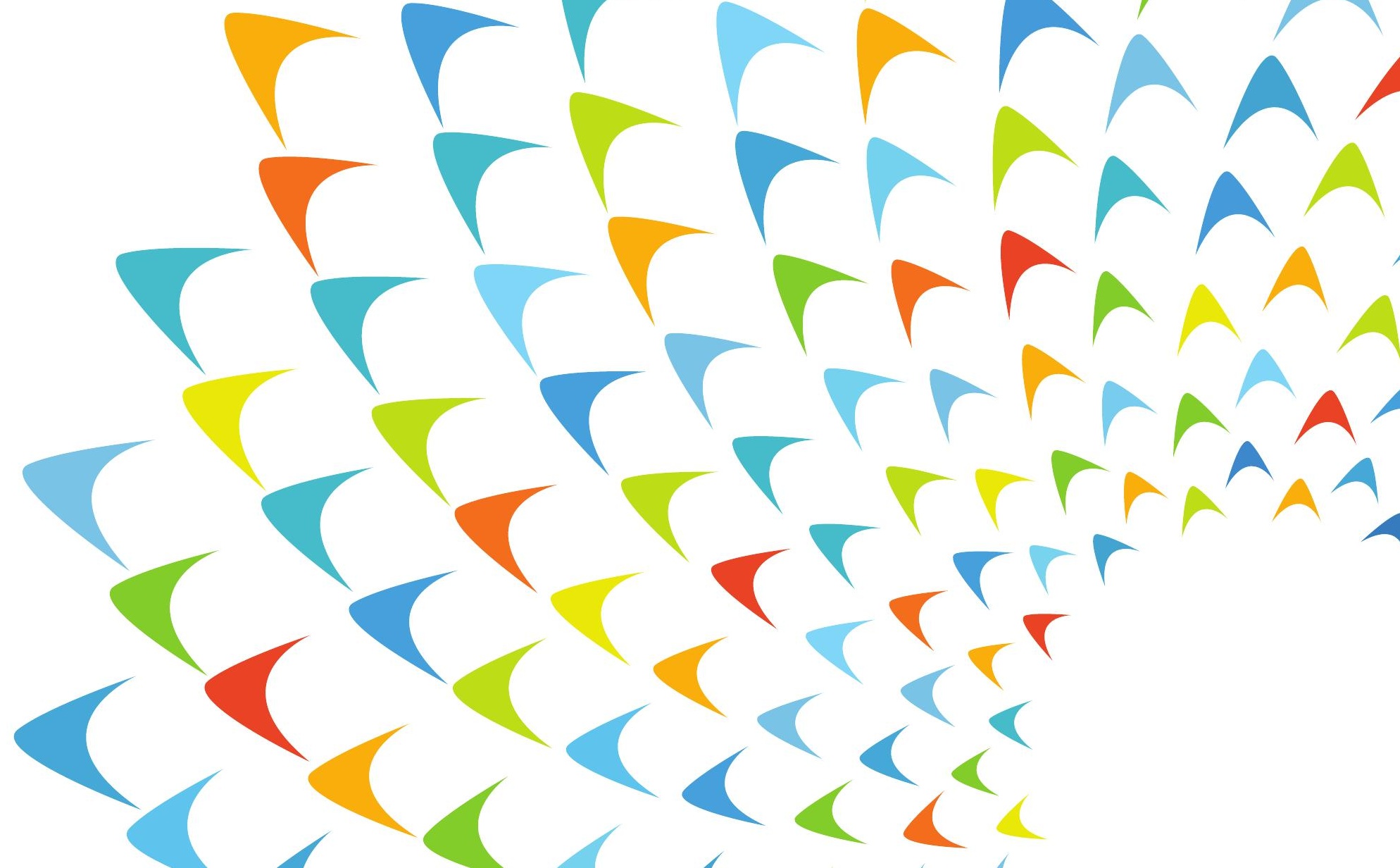




\section{VISISTRATEGI 2030}

ASIA DAN PASIFIK YANG

MAKMUR

INKLUSIF

TANGGUH

BERKELANJUTA, 


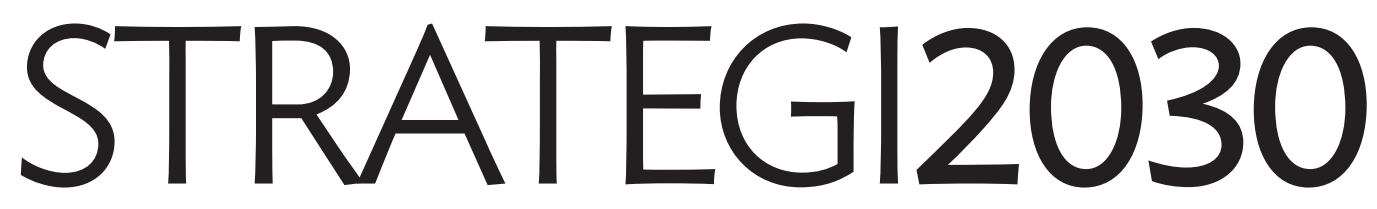

Mencapai Asia dan Pasifik yang Makmur, Inklusif, Tangguh, dan Berkelanjutan

JULI 2018 
(c) 2018 Asian Development Bank

6 ADB Avenue, Mandaluyong City, 1550 Metro Manila, Filipina

Tel +632632 4444; Faks +6326362444

www.adb.org

Semua hak dilindungi undang-undang. Diterbitkan pada 2018.

ISBN 978-92-9261-284-9 (cetak), 978-92-9261-285-6 (elektronik)

Stok Publikasi No. TCS189401-2

DOI: http://dx.doi.org/10.22617/TCS189401-2

ADB tidak menjamin keakuratan data dalam publikasi ini dan tidak bertanggung jawab atas akibat yang timbul dari penggunaannya. Penyebutan perusahaan tertentu atau produk tertentu dari produsen tidak berarti bahwa ADB lebih mendukung atau merekomendasikan perusahaan atau produk tersebut dibandingkan dengan perusahaan atau produk sejenis lainnya yang tidak disebutkan.

Dengan menyebut atau merujuk pada wilayah atau daerah geografis tertentu, atau dengan menggunakan istilah "negara" dalam dokumen ini, ADB tidak bermaksud membuat penilaian apa pun mengenai status hukum atau status lainnya atas suatu wilayah atau daerah.

ADB menganjurkan agar pencetakan atau penggandaan informasi dalam publikasi ini hanya untuk keperluan pribadi, pendidikan, dan nonkomersial, dengan menyebutkan ADB sebagai sumbernya. Pengguna dilarang memperjualbelikan, mengedarkan, atau membuat karangan berdasarkan publikasi ini untuk tujuan komersial tanpa izin tertulis tegas dari ADB. Silakan hubungi pubsmarketing@adb.org jika ada pertanyaan atau komentar mengenai isi publikasi ini, atau jika Anda ingin memperoleh izin hak cipta.

Catatan:

Dalam publikasi ini, “\$” mengacu pada dolar Amerika Serikat.

ADB mengakui “Tiongkok” sebagai Republik Rakyat Tiongkok dan "Korea” sebagai Republik Korea.

Daftar ralat berbagai publikasi ADB dapat dilihat di http://www.adb.org/publications/corrigenda.

3

Dicetak di kertas daur ulang

Tentang Sampul: Deret Fibonacci

Fibonacci adalah matematikawan abad pertengahan yang memperkenalkan deret angka yang setiap angkanya adalah penjumlahan dari dua angka terdahulu: 0, 1, 1, 2, 3, 5, 8, 13, dan seterusnya. Deret angka ini juga terlihat di alam, seperti pada susunan daun di sekitar batang.

Konsep desain Strategi 2030 didasarkan pada deret Fibonacci, mewakili haluan baru penuh pertimbangan dan dinamis yang ditetapkan Strategi 2030 bagi ADB. 


\section{DAFTAR ISI}

Singkatan iv

Ringkasan Eksekutif $\quad v$

$\begin{array}{ll}\text { I. Pendahuluan } & 1\end{array}$

II. Keadaan Dan Tantangan Yang Sudah Berubah 3

$\begin{array}{ll}\text { III. Visi Dan Nilai Tambah ADB } & 10\end{array}$

IV. Prinsip-Prinsip Pemandu Operasi ADB 13

V. Pendekatan Berbeda Untuk Berbagai Kelompok Negara 14

$\begin{array}{ll}\text { VI. Prioritas Operasional } & 17\end{array}$

VII. Memperluas Operasi Sektor Swasta 24

VIII. Mengkatalisasi Dan Memobilisasi Sumber Daya Keuangan
Untuk Pembangunan

IX. Memperkuat Layanan Pengetahuan 30

X. Menyampaikan Hasil Melalui Adb Yang Lebih Kuat, Lebih Baik, Dan Lebih Cepat $\quad 32$

XI. Satu ADB $\quad 35$

Lampiran: Mengkaji Kembali Operasi ADB Dan Rangkuman Konsultasi 36 


\title{
SINGKATAN
}

\author{
ADB Asian Development Bank \\ ADF Asian Development Fund (Dana Pembangunan Asia) \\ ASEAN Association of Southeast Asian Nations (Asosiasi Negara-Negara Asia Tenggara) \\ CPS \\ CSO \\ country partnership strategy (strategi kemitraan negara) \\ DEfR \\ civil society organization (organisasi masyarakat madani) \\ DMC \\ development effectiveness review (tinjauan efektivitas pembangunan) \\ FAO \\ developing member country (negara berkembang anggota ADB) \\ FCAS \\ Food and Agriculture Organization of the United Nations (Organisasi Pangan dan Pertanian PBB) \\ GHG \\ ICT \\ fragile and conflict-affected situations (kondisi yang rapuh dan terdampak konflik) \\ greenhouse gas (gas rumah kaca) \\ $\begin{array}{ll}\text { IED } & \text { Independent Evaluation Departm } \\ \text { Lao PDR } & \text { Republik Rakyat Demokratik Laos }\end{array}$ \\ information and communication technology (teknologi informasi dan komunikasi) \\ OCR ordinary capital resources (sumber daya modal biasa) \\ PBL policy-based lending (pinjaman berbasis kebijakan) \\ PPP public-private partnership (kerja sama pemerintah-badan usaha) \\ PRC Republik Rakyat Tiongkok \\ $\mathrm{RCl} \quad$ regional cooperation and integration (kerja sama dan integrasi kawasan) \\ SDG Sustainable Development Goal (Sasaran Pembangunan Berkelanjutan) \\ SIDS small island developing states (negara pulau kecil yang berkembang) \\ SME small and medium-sized enterprises (usaha kecil dan menengah) \\ SOE state-owned enterprise (badan usaha milik negara) \\ TA technical assistance (bantuan teknis) \\ UMIC upper middle-income country (negara berpenghasilan menengah-atas) \\ UNICEF United Nations Children's Fund \\ WFP World Food Programme (Program Pangan Dunia) \\ WHO World Health Organization (Organisasi Kesehatan Dunia)
}




\section{RINGKASAN EKSEKUTIF 77}

ASIA DAN PASIFIK telah mengalami kemajuan pesat dalam pengurangan kemiskinan dan pertumbuhan ekonomi selama 50 tahun terakhir. Namun, masih ada agenda pembangunan yang belum selesai. Masalah seperti kemiskinan dan kerentanan, meningkatnya ketimpangan, perubahan iklim, makin kuatnya tekanan terhadap lingkungan, dan besarnya defisit infrastruktur belum teratasi. Sejumlah tren yang muncul, seperti kemajuan teknologi, urbanisasi, dan perubahan demografi, membawa peluang sekaligus tantangan.

Mengingat luasnya wilayah Asia dan Pasifik, pencapaian sejumlah komitmen global utama-seperti Sasaran Pembangunan Berkelanjutan (Sustainable Development Goals), agenda Pembiayaan Pembangunan (Financing for Development) yang berkaitan, Kesepakatan Paris tentang perubahan iklim, dan Kerangka Kerja Sendai untuk Pengurangan Risiko Bencana (Sendai Framework for Disaster Risk Reduction)—akan sangat bergantung pada keberhasilan di kawasan ini.

Strategi 2030 mengarahkan Asian Development Bank (ADB) agar dapat efektif menanggapi perubahan kebutuhan di kawasan ini. Dengan Strategi 2030, ADB akan melanjutkan upayanya memberantas kemiskinan ekstrem dan memperluas visinya untuk mencapai Asia dan Pasifik yang makmur, inklusif, tangguh, dan berkelanjutan. Aspirasi ADB selaras dengan komitmen global utama.

ADB akan berperan penting dalam mendukung agenda global pembangunan infrastruktur sebagai sumber pertumbuhan global. Infrastruktur akan tetap menjadi prioritas penting guna mendorong pembangunan sosial dan ekonomi. ADB akan mendorong investasi infrastruktur berkualitas yang ramah lingkungan, berkelanjutan, tangguh, dan inklusif. Pada saat bersamaan, ADB akan memperluas intervensi di sektor sosial, seperti pendidikan, kesehatan, dan perlindungan sosial. ADB juga akan berupaya mengintegrasikan keahliannya di berbagai sektor dan tema untuk menjawab tantangan pembangunan yang lebih rumit.
Sebagai mitra pembangunan tepercaya, ADB akan memberi nilai tambah bagi negara berkembang anggotanya (developing member country - DMC) dengan menggabungkan pembiayaan, pengetahuan, dan kemitraan. ADB akan terus menjadi penyedia pembiayaan yang dapat diandalkan dan pengkatalisasi pembiayaan. Sebagai penyedia pengetahuan, ADB akan berfokus pada nilai praktis yang sesuai kondisi setempat, mengidentifikasi pembelajaran, dan mereplikasi praktik baik ke seluruh kawasan ini dan lebih luas lagi. Sebagai penggagas kemitraan, ADB akan mendorong dialog dan kerja sama di antara berbagai mitra dan pemangku kepentingan, serta berupaya memaksimalkan dampak sistem lembaga keuangan internasional secara keseluruhan. ADB juga akan meningkatkan fungsinya sebagai pengembang proyek.

Agenda pembangunan global yang ambisius harus disesuaikan dengan keadaan setempat yang spesifik. ADB akan memperkuat pendekatan berfokus negara dengan menggunakan strategi kemitraan negara (country partnership strategy - CPS) sebagai platform utama untuk menentukan dukungan yang disesuaikan, mendorong penggunaan teknologi inovatif, dan menyampaikan solusi terintegrasi dengan menggabungkan keahlian berbagai sektor dan tema, serta melaluigabungan operasi sektor publik dan swasta. $A D B$ akan selektif di tingkat negara-melanjutkan upaya berdasarkan keunggulan komparatif ADB, kebutuhan spesifik negara yang bersangkutan, dan potensi memberi nilai tambah dalam batas kapasitas dan sumber daya ADB.

Mengingat keragaman yang besar di antara berbagai negara, ADB akan menerapkan pendekatan yang berbeda-beda untuk kelompok negara yang berlainan. ADB akan terus memprioritaskan dukungan bagi negara-negara termiskin dan paling rentan di kawasan ini, termasuk kondisi yang rapuh dan terdampak konflik serta negara pulau kecil yang berkembang. ADB akan menyesuaikan proses bisnis dan memperkuat sumber daya serta kehadiran di lapangan untuk negara-negara 
tersebut. ADB akan memberi pembiayaan jangka panjang yang dapat diprediksi dan bernilai besar untuk mendukung negara berpenghasilan rendah dan menengah-bawah. Dukungan ADB bagi negara berpenghasilan menengah-atas akan bersifat selektif, dengan fokus pada bidang-bidang yang dapat diberi nilai tambah terbesar. Di antara berbagai kelompok negara itu, $A D B$ akan memprioritaskan dukungan bagi daerah tertinggal, dan kantung kemiskinan dan kerentanan.

ADB akan terus menerapkan kebijakan kelulusan saat ini, sambil meninjau efektivitas kebijakan tersebut. Kelulusan dari bantuan ADB reguler akan melibatkan konsultasi mendalam dengan negara tersebut, termasuk analisis dan penilaian elemen penting kebijakan kelulusan. Sebagai bagian dari pendekatan yang berbeda-beda, ADB akan melakukan analisis terperinci dan berdiskusi dengan berbagai pemangku kepentingan mengenai peluang memvariasikan ketentuan pembiayaan produk dan instrumen ADB. $A D B$ akan mengarahkan pembiayaan konsesional untuk mendukung negara-negara anggota yang paling miskin dan paling rentan, serta akan mempertimbangkan dukungan tambahan bagi negara yang baru lulus dari bantuan konsesional.

Dukungan ADB (termasuk operasi sektor publik dan swasta, layanan konsultasi, dan pengetahuan) akan difokuskan pada prioritas operasional penting berikut.

i. Mengatasi kemiskinan yang masih ada dan mengurangi ketimpangan. $A D B$ akan meningkatkan penekanan pada perkembangan manusia dan inklusi sosial untuk menjawab dimensi non-pendapatan dari kemiskinan. ADB akan membantu memfasilitasi penciptaan pekerjaan berkualitas, termasuk oleh usaha kecil dan menengah, serta usaha yang inklusif. ADB akan mendukung negara berkembang anggotanya (DMC) dalam meningkatkan hasil pendidikan dan pelatihan, mencapai kesehatan yang lebih baik bagi semua orang, serta memperkuat sistem perlindungan sosial dan penyampaian layanan bagi orang-orang yang membutuhkannya.

ii. Mempercepat kemajuan dalam kesetaraan gender. ADB akan mendukung operasi yang tepat sasaran untuk memberdayakan perempuan dan anak perempuan, pengarusutamaan gender yang secara langsung memperkecil kesenjangan gender, dan operasi dengan beberapa elemen gender di dalamnya yang memasukkan tindakan kesetaraan gender dalam perancangan dan pelaksanaan proyek dan program ADB. Setidaknya 75\% dari jumlah operasi yang sudah menjadi komitmen ADB (berdasarkan rata-rata bergerak 3 tahun, termasuk operasi sektor publik dan swasta) akan mendorong kesetaraan gender sampai dengan 2030.

iii. Menghadapi perubahan iklim, membangun ketangguhan terhadap iklim dan bencana, serta meningkatkan kelestarian lingkungan. ADB akan meningkatkan dukungan di bidang-bidang tersebut. ADB akan memastikan bahwa 75\% dari jumlah operasi yang sudah menjadi komitmen ADB (berdasarkan rata-rata bergerak 3 tahun, termasuk operasi sektor publik dan swasta) akan mendukung mitigasi dan adaptasi perubahan iklim sampai dengan 2030. Pembiayaan iklim dari sumber daya ADB sendiri akan mencapai $\$ 80$ miliar secara kumulatif untuk periode 2019 sampai 2030.

iv. Menjadikan kota lebih layak huni. ADB akan memberi solusi terintegrasi untuk membantu membangun kota layak huni yang ramah lingkungan, kompetitif, tangguh, dan inklusif. Selain itu, ADB juga akan menjalankan proyek lintas-bidang untuk mendorong kesehatan perkotaan, mobilitas perkotaan, kesetaraan gender, dan kelestarian lingkungan. $A D B$ akan membantu kota menggali sumber pendanaan baru dan memperluas yang sudah ada, meningkatkan perencanaan perkotaan yang inklusif dan partisipatif, serta mengintegrasikan pertimbangan tentang ketangguhan terhadap iklim dan manajemen risiko bencana ke dalam proses perencanaan perkotaan.

v. Mendorong pembangunan perdesaan dan ketahanan pangan. ADB akan mendukung upaya untuk meningkatkan konektivitas pasar dan kaitan ke rantai nilai pertanian. ADB akan membantu DMC menambah produktivitas pertanian dan ketahanan pangan dengan membantu meningkatkan pendapatan tani dan nontani, mendorong adopsi teknologi maju dan praktik pertanian yang cerdas 
iklim, dan mendukung penyempurnaan standar manajemen sumber daya alam. ADB juga akan membantu DMC meningkatkan keamanan pangan.

vi. Memperkuat tata kelola dan kapasitas kelembagaan. ADB akan mendukung reformasi manajemen publik guna membantu DMC meningkatkan tata kelola dan menciptakan lingkungan yang memungkinkan pertumbuhan berkelanjutan. ADB akan membantu berbagai negara membangun ketangguhan dan menanggapi guncangan ekonomi, memperkuat penyampaian layanan, serta meningkatkan kapasitas dan standar. ADB akan menegakkan perlindungan lingkungan dan sosial, taat pada standar fidusia, dan melaksanakan langkah-langkah antikorupsi dalam semua proyek dan programnya.

vii. Mendorong kerja sama dan integrasi kawasan. ADB akan meningkatkan konektivitas di kawasan dan daya saing DMC. ADB akan memperbesar dukungan bagi barang publik untuk kawasan dan tindakan kolektif guna memitigasi risiko lintas batas seperti perubahan iklim, polusi, ketahanan energi dan keamanan pasokan air, serta penyakit menular dan infeksi. ADB juga akan meningkatkan kerja sama sektor keuangan dan memperkuat prakarsa subkawasan, termasuk dengan memfasilitasi berbagi pengetahuan dan kerja sama, serta bekerja sama dengan prakarsa-prakarsa yang baru muncul.

ADB akan memperluas operasi sektor swastanya hingga mencapai sepertiga dari keseluruhan jumlah operasi ADB sampai dengan 2024. ADB akan mengejar dampak pembangunan sebagai tujuan penting operasi sektor swasta. ADB juga akan memastikan profitabilitas dan keberlanjutan komersial. ADB akan memperluas dan mendiversifikasi operasi sektor swasta ke tempat-tempat baru, seperti kawasan yang rapuh dan terdampak konflik, serta negara pulau kecil yang sedang berkembang. ADB akan menggunakan dana ekuitas swasta untuk memperluas jangkauannya dan meningkatkan dukungan bagi kerja sama pemerintahbadan usaha. ADB juga akan meningkatkan jumlah staf sektor swastanya di lapangan.

ADB akan mengkatalisasi dan memobilisasi sumber daya keuangan untuk pembangunan. $A D B$ akan memperkuat kerja sama dengan mitra multilateral, bilateral, dan sektor swasta. ADB juga akan mencari pembiayaan dari sumber komersial dan konsesional. ADB akan menargetkan kenaikan besar pembiayaan bersama (cofinancing) jangka panjang sampai dengan 2030 , dengan setiap $\$ 1$ pembiayaan untuk operasi sektor swastanya diimbangi dengan $\$ 2,50$ pembiayaan bersamajangka panjang. Untukmengkatalisasi investasi, ADB akan menggunakan kerja sama pemerintahbadan usaha, menyempurnakan lingkungan usaha di DMC, dan meningkatkan mobilisasi sumber daya domestik DMC.

ADB akan memperkuat peran sebagai penyedia pengetahuan. ADB akan bekerja sama erat dengan DMC guna mengidentifikasi kebutuhan DMC dan menghasilkan produk dan layanan pengetahuan yang paling relevan. ADB akan memberi insentif bagi staf untuk mengintegrasikan pengetahuan terbaik yang tersedia dengan pembiayaan dan peningkatan kapasitas kelembagaan di sepanjang siklus operasional. ADB akan proaktif melakukan penelitian, memberi saran kebijakan berkualitas bagi DMC, memperkuat kapasitas kelembagaan DMC dalam mengatasi masalah pembangunan dan penyampaian proyek, serta memperluas kemitraan pengetahuan. ADB juga akan mendorong penciptaan dan berbagi pengetahuan di seluruh organisasi dan kawasan.

ADB akan terus berupaya agar dapat menjadi lebih kuat, lebih baik, dan lebih cepat. ADB akan memastikan basis sumber daya yang kuat untuk mendukung operasi di masa mendatang. ADB akan memperkuat sumber daya manusia dan memperdalam keberadaan di berbagai negara melalui kantor perwakilan yang lebih kuat. ADB akan menyempurnakan produk dan instrumennya. ADB akan menjalankan modernisasi dramatis proses bisnis (termasuk pengadaan tepat waktu dan hemat biaya, serta penggunaan lebih besar sistem negara) dan mempercepat transformasi digitalnya. ADB akan memperkuat kerja sama dengan organisasi masyarakat madani dalam merancang, melaksanakan, dan memantau berbagai proyek.

Untuk operasionalisasi strategi ini, ADB akan mengembangkan rencana operasional bagi tujuh bidang prioritas guna menjabarkan fokus strategis, bidang pelibatan spesifik, pendekatan, dan persyaratan 
keterampilan secara umum. Strategi kemitraan negara akan lebih menajamkan prioritas di tingkat negara. Program kerja dan proses kerangka kerja anggaran akan diperkuat dan digunakan untuk menyelaraskan rencana kerja tahunan, serta pengaturan sumber daya dengan prioritas operasional. Kerangka kerja hasil korporasi yang baru akan dikembangkan dan diperbarui untuk memantau dan mengukur kemajuan pelaksanaan.
ADB akan terus melanjutkan laporan tahunan tentang kinerja kelembagaan dengan menggunakan kerangka kerja hasil.

ADB akan menjalankan pendekatan "Satu ADB (One $A D B)$ " guna menyatukan pengetahuan dan keahlian dari seluruh bagian organisasi agar efektif melaksanakan Strategi 2030. 


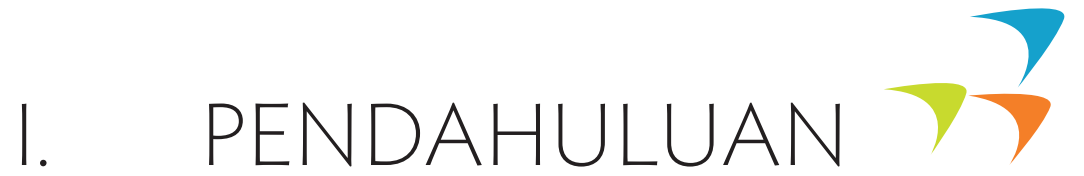

1. Asia dan Pasifik telah mengalami kemajuan pesat dalam pengurangan kemiskinan dan pertumbuhan ekonomi dalam 50 tahun terakhir.' Kawasan ini punya aspirasi untuk maju bahkan lebih pesat lagi ke depannya. Asian Development Bank (ADB) telah menjadi mitra penting dalam transformasi signifikan kawasan ini dan berkomitmen untuk terus melayani kawasan ini pada tahap pembangunan berikutnya.

2. Strategi korporasi jangka panjang yang baru menuju 2030-Strategi 2030-mengarahkan upaya ADB agar dapat efektif menanggapi perubahan kebutuhan di kawasan ini. Strategi 2030 melanjutkan dari berbagai kajian kinerja ADB, termasuk Kajian Tengah Waktu Strategi 2020 (Midterm Review of Strategy 2020), tinjauan efektivitas pembangunan (development effectiveness review DefR), dan studi oleh Departemen Evaluasi Independen (Independent Evaluation Department - IED).

3. Kajian Tengah Waktu Strategi 2020. Kajian tengah waktu pada tahun 2014 menghasilkan pembelajaran dari pelaksanaan Strategi 2020 dan menawarkan program 10 butir guna menajamkan dan menyeimbangkan kembali arah strategis ADB di masa mendatang dan memperkuat kecepatan tanggap ADB. ${ }^{2}$ Program tersebut ditujukan untuk memperkuat upaya dalam pengurangan kemiskinan, pertumbuhan ekonomi yang inklusif, lingkungan dan perubahan iklim, kerja sama dan integrasi kawasan (regional cooperation and integration
- $\mathrm{RCl}$ ), pembangunan infrastruktur, negara berpenghasilan menengah, pengembangan dan operasi sektor swasta, serta solusi pengetahuan. Program tersebut juga mencakup tindakan untuk meningkatkan kapasitas, efisiensi, dan efektivitas ADB di bidang-bidang seperti sumber daya dan kemitraan keuangan, proses bisnis, keterampilan staf, insentif, dan pengaturan kelembagaan.

4. Penilaian kinerja ADB. Temuan dari tinjauan efektivitas pembangunan (DefR), yang mengkaji kembali kinerja ADB dan membandingkannya dengan kerangka kerja hasil korporasi setiap tahun, dan evaluasi dari Departemen Evaluasi Independen (IED) memperkuat temuan dari kajian tengah waktu. Temuan-temuan tersebut menunjukkan bahwa operasi ADB sudah selaras dengan prioritas Strategi 2020 dan memberi hasil positif di berbagai bidang seperti infrastruktur, perubahan iklim, dan gender. Namun, temuan tersebut juga menunjukkan bahwa ADB perlu sedikit menyeimbangkan kembali portofolionya dan meningkatkan fokus pada sektor sosial guna memperkuat dukungan bagi pengurangan kemiskinan dan pertumbuhan ekonomi yang inklusif. Diusulkan pula penekanan yang lebih besar pada operasi sektor swasta sebagai tanggapan atas berkembangnya kebutuhan kawasan, termasuk untuk memobilisasi lebih banyak sumber daya. IED menganjurkan ADB untuk mengejar pertumbuhan yang berkualitas lebih baik (bukan sekadar taraf pertumbu-

\section{Strategi korporasi jangka panjang yang baru menuju 2030-Strategi 2030 - mengarahkan upaya ADB agar dapat efektif menanggapi perubahan kebutuhan di kawasan ini.}

\footnotetext{
"Asia dan Pasifik" mengacu pada 48 perekonomian di Asia dan Pasifik yang merupakan anggota Asian Development Bank (ADB). Berbagai perekonomian ini secara umum dikelompokkan menjadi anggota dari perekonomian berkembang dan anggota dari perekonomian maju. Istilah "anggota dari perekonomian maju" mengacu pada Australia, Jepang, dan Selandia Baru. Sisa 45 anggota dari perekonomian berkembang secara kolektif disebut sebagai "kawasan Asia yang sedang berkembang."

2 ADB. 2014. Kajian Tengah Waktu Strategi 2020: Menjawab Tantangan di Tengah Transformasi Asia dan Pasifik. Manila.
} 


\section{Strategi 2030 mencerminkan masukan dari rangkaian luas pemangku kepentingan, termasuk pembuat kebijakan di negara berkembang dan maju, akademisi, dan organisasi masyarakat madani, serta anggota dan staf Dewan ADB.}

han) melalui tiga agenda yang saling memperkuat, yaitu inklusi sosial dan geografis, kelestarian lingkungan, serta kerja sama dan integrasi kawasan (RCI). IED juga mengusulkan agar ADB sebaiknya mengintegrasikan keahlian di berbagai sektor dan tema untuk menjawab tantangan pembangunan yang lebih rumit di bawah Strategi 2030.

5. Masukan dari konsultasi dengan pemangku kepentingan. Strategi 2030 mencerminkan masukan dari rangkaian luas pemangku kepentingan, termasuk pembuat kebijakan di negara berkembang dan maju, akademisi, dan organisasi masyarakat madani (civil society organization - CSO), serta anggota dan staf Dewan ADB. Empat diskusi meja bundar bersama para pemikir pembangunan terkemuka telah diadakan di London, Manila, Tokyo, dan Washington, DC, ditambah lagi dengan konsultasi dengan berbagai negara di kawasan ini. Para pemangku kepentingan menekankan bahwa ADB masih memiliki peran penting di Asia dan Pasifik meskipun sebagian besar negara berkembang anggotanya (DMC) telah mencapai status negara berpenghasilan menengah. Banyak DMC yang masih menghadapi tantangan akibat kemiskinan dan kerentanan yang sudah mengakar, ketidakpastian perekonomian global, ketimpangan, perubahan iklim dan degradasi lingkungan, urbanisasi, dan penuaan. ADB perlu terus mengembangkan keunggulannya dalam pembiayaan infrastruktur dan $\mathrm{RCl}$; memperkuat kapasitas di sektor sosial; dan memperluas operasi sektor swasta, termasuk kerja sama pemerintah-badan usaha (public-private partnership - PPP), guna membantu DMC mengatasi berbagai tantangan tersebut. Lebih lanjut lagi, ADB perlu memperkuat layanan pengetahuan, memfasilitasi lebih banyak berbagi pengetahuan ke berbagai negara, dan meningkatkan efisiensi proses bisnis. ${ }^{3}$

Temuan dari penilaian tersebut dan rangkuman konsultasi dengan pemangku kepentingan dapat dilihat di bagian lampiran. 


\section{KEADAAN DAN TANTANGAN YANG SUDAH BERUBAH}

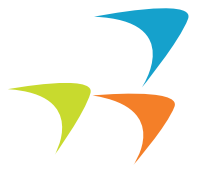

\section{Peralihan pusat perekonomian ke Asia dan Pasifik.} Sebagai kawasan yang tumbuh paling cepat dalam beberapa dekade terakhir, persentase Asia dan Pasifik dalam produk domestik bruto global meningkat dari 25\% pada 2000 menjadi 33\% pada 2016 (Gambar 1). Kawasan ini diperkirakan akan menguasai lebih dari setengah produksi global pada 2050. ${ }^{4}$ Republik Rakyat Tiongkok (RRT) dan India kini termasuk dalam deretan perekonomian terbesar di dunia. Berbagai negara yang tergabung di dalam Asosiasi Negara-Negara Asia Tenggara (Association of Southeast Asian Nations - ASEAN), ${ }^{5}$ yang secara kolektif memiliki jumlah penduduk hampir 640 juta, telah menjadi perekonomian berkembang yang penting dan berorientasi pasar. Pertumbuhan kuat telah menghasilkan penurunan dramatis kemiskinan pendapatan dan peningkatan standar kehidupan. Kemiskinan ekstrem, yang diukur dengan ambang batas $\$ 1,90 /$ hari pada paritas daya beli 2011, telah turun signifikan di kawasan Asia yang sedang berkembang dari 53\% pada 1990 menjadi sekitar 9\% dari jumlah penduduk pada 2013. ${ }^{6}$ Meskipun tren positif ini diperkirakan akan terus berlanjut, kemiskinan masih tetap ada. Kawasan ini juga menghadapi keadaan pembangunan yang dinamis dan makin rumit akibat peristiwa global dan tantangan kawasan yang bermunculan.

\section{Masih ada kemiskinan dan kerentanan.} Mengurangi kemiskinan di Asia dan Pasifik, bahkan di negara-negara dengan pendapatan per kapita relatif tinggi, masih menjadi agenda yang belum selesai. Meskipun sudah ada kemajuan besar, 326 juta orang yang tinggal di kawasan ini masih hidup dalam ke-

ADB. 2011. Asia 2050: Realizing the Asian Century. Singapura.

Sepuluh negara anggota ASEAN adalah Brunei Darussalam, Kamboja, Indonesia, Republik Rakyat Demokratik Laos, Malaysia, Myanmar, Filipina, Singapura, Thailand, dan Viet Nam.

6 Bank Dunia. PovcalNet. http://iresearch.worldbank.org/PovcalNet/ home.aspx (diakses 11 Oktober 2017). Perkiraan kemiskinan untuk kawasan Asia yang sedang berkembang dihitung dari 34 DMC yang datanya tersedia: Armenia, Azerbaijan, Bangladesh, Bhutan, Fiji, Filipina, Georgia, India, Indonesia, Kazakhstan, Kirgistan, Kiribati, Laos, Maladewa, Malaysia, Mongolia, Myanmar, Negara Federasi Mikronesia, Nepal, Pakistan, Papua Nugini, RRT, Samoa, Kepulauan Solomon, Sri Lanka, Tajikistan, Thailand, Timor-Leste, Tonga, Turkmenistan, Tuvalu, Uzbekistan, Vanuatu, Viet Nam.

\section{Gambar 1: Porsi Asia dan Pasifik yang Makin Meningkat pada Produk Domestik Bruto Global, 2000 dan 2016}
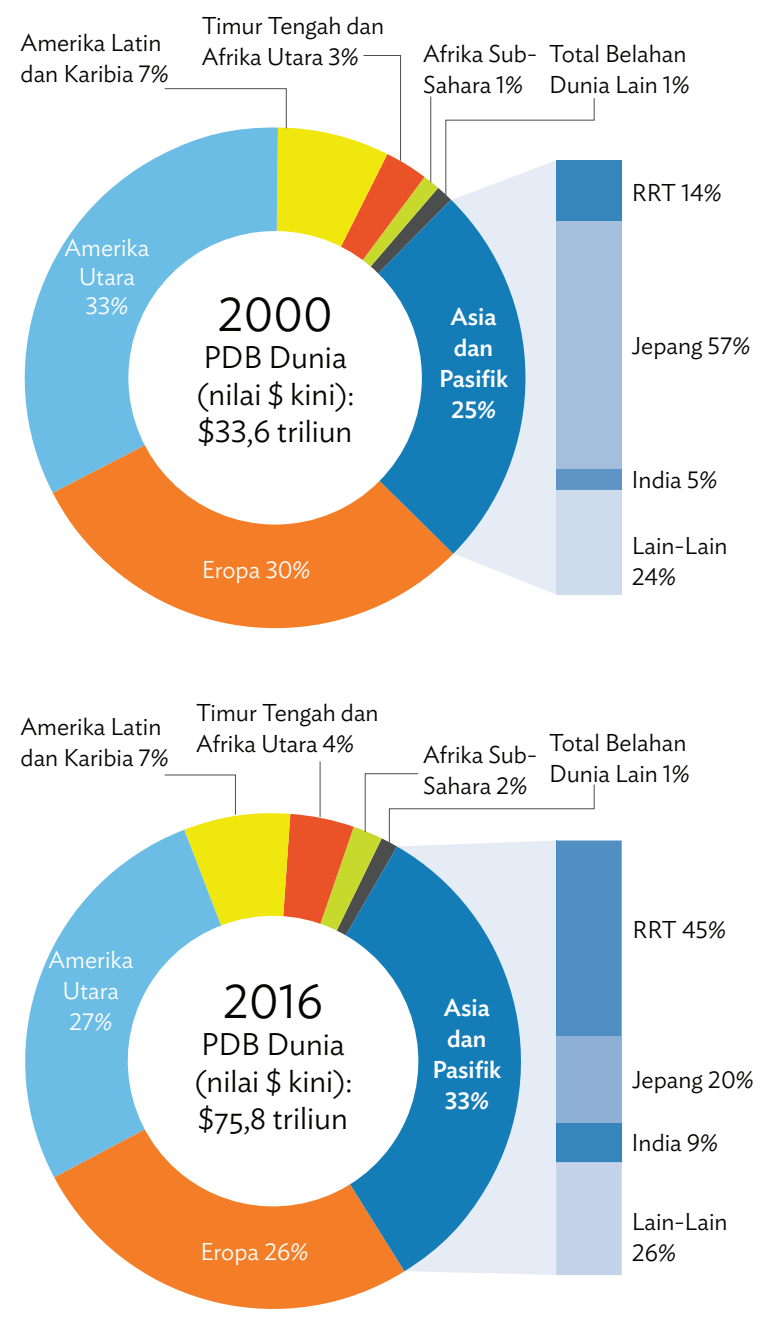

$\mathrm{ADB}=$ Asian Development Bank, $\mathrm{PDB}=$ produk domestik bruto, $\mathrm{RRT}=$ Republik Rakyat Tiongkok.

Catatan: Asia dan Pasifik mencakup perekonomian anggota ADB dari negara berkembang dan negara maju, kecuali Kepulauan Cook dan Taipei, yang datanya tidak tersedia. Nilai dolar untuk PDB dikonversi dari mata uang domestik dengan menggunakan nilai tukar resmi tahun tunggal.

Sumber: Bank Dunia. Indikator Pembangunan Dunia (WDI) http://databank.worldbank.org/data/reports.aspx? source=worlddevelopment-indicators (diakses 5 Maret 2018). 


\section{Gambar 2: Kemiskinan dan Kerentanan di Negara Berkembang Anggota ADB}

\subsection{6 juta}

\section{Tingkat kemiskinan $81 \%$}

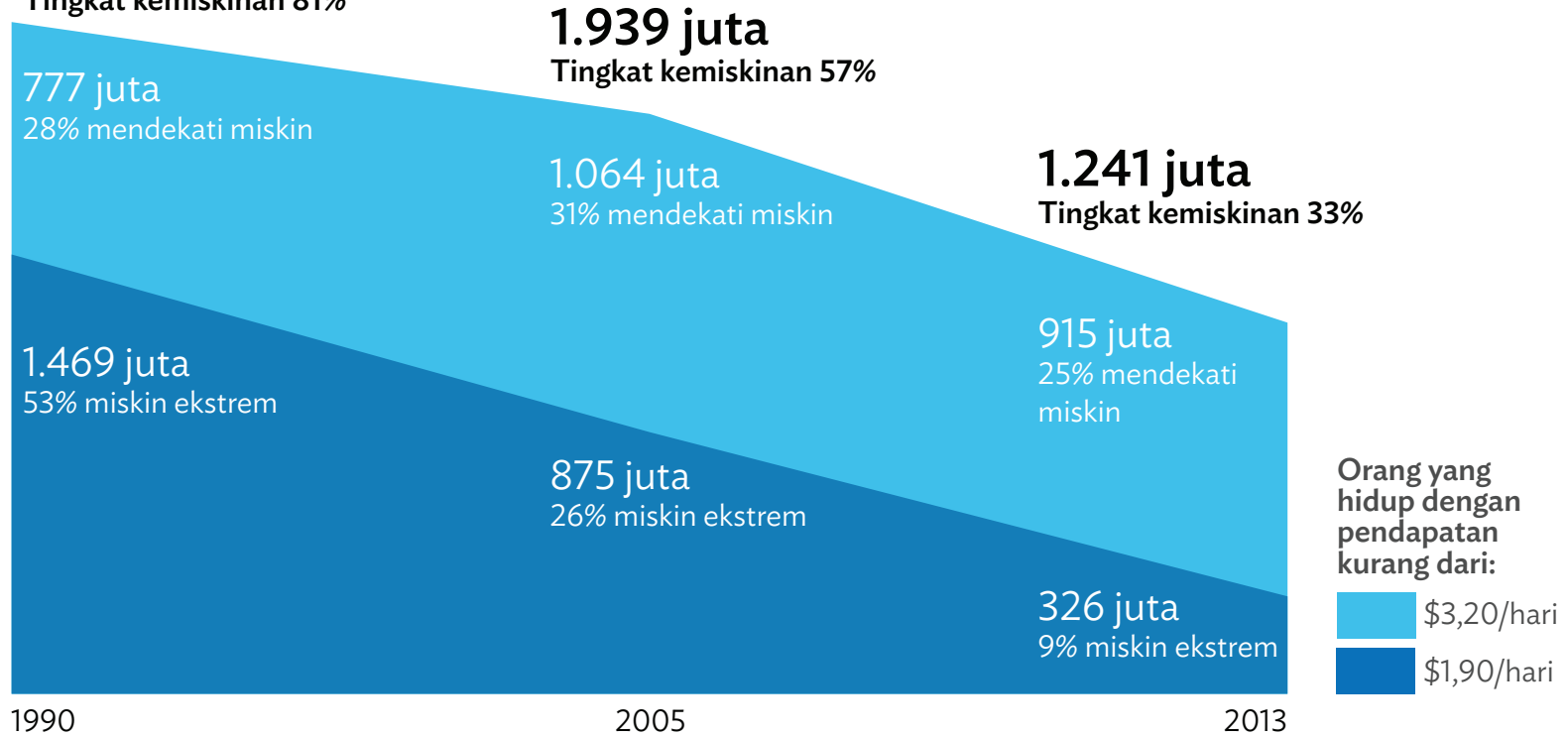

$\mathrm{ADB}=$ Asian Development Bank

Catatan: Tahun referensi terakhir untuk perkiraan kemiskinan adalah 2013. Garis kemiskinan dinyatakan pada paritas daya beli 2011. Penjumlahan beberapa angka mungkin tidak sesuai karena pembulatan.

Sumber: Bank Dunia. PovcalNet. http://iresearch.worldbank.org/PovcalNet/home.aspx (diakses 11 Oktober 2017).

miskinan ekstrem (atau berada di bawah garis kemiskinan \$1,90/hari) pada tahun 2013 (Gambar 2). Selain itu, 915 juta orang lagi hidup di atas $\$ 1,90 /$ hari tetapi di bawah $\$ 3,20 /$ hari. Orang-orang ini terus menghadapi risiko terjerumus kembali ke dalam kemiskinan ekstrem ketika terjadi kemerosotan ekonomi dan guncangan eksternal lainnya. Jumlah orang yang menghadapi kerawanan pangan masih signifikan: 64\% dari orang-orang yang kekurangan gizi di dunia (hampir 520 juta orang) tinggal di Asia pada $2016 .^{7}$
8. Meningkatnya ketimpangan. Ketimpangan pendapatan telah meningkat di beberapa negara dan masih ada disparitas sosial. Hampir $80 \%$ penduduk di kawasan ini tinggal di negara-negara dengan ketimpangan yang terus melebar (diukur dengan koefisien Gini) antara tahun 1990-an hingga 2000-an. $8^{8}$ Insidensi kemiskinan masih lebih tinggi di daerah perdesaan daripada perkotaan, dan terdapat disparitas besar pada partisipasi sekolah dan pencapaian pembelajaran, serta akses terhadap listrik, sumber air, dan sanitasi. ${ }^{9}$ Kesenjangan gender sistemik dalam produktivitas,

Organisasi Pangan dan Pertanian PBB (FAO), International Fund for Agricultural Development, United Nations Children's Fund (UNICEF), Program Pangan Dunia (WFP), dan Organisasi Kesehatan Dunia (WHO). 2017. The State of Food Security and Nutrition in the World 2017: Building Resilience for Peace and Food Security. Roma: FAO. Kekurangan gizi didefinisikan sebagai keadaan ketika konsumsi pangan sehari-hari seseorang tidak mencukupi untuk memberi jumlah energi yang diperlukan guna menjalani kehidupan yang normal, aktif, dan sehat. Perkiraan untuk Asia didasarkan pada klasifikasi negara oleh FAO.

8 Bank Dunia. Indikator Pembangunan Dunia (WDI). http://databank.worldbank.org/data/reports.aspx?source=world-development-indicators (diakses 15 Februari 2018). Dari 22 negara dengan data yang dapat dibandingkan, 8 negara (India, Indonesia, Laos, Mongolia, RRT, Sri Lanka, Tajikistan, dan Viet Nam) -yang mencakup sekitar 79\% dari keseluruhan jumlah penduduk di kawasan Asia yang sedang berkembang pada 2015-mengalami kenaikan koefisien Gini antara tahun 1990-an hingga tahun 2000-an.

9 ADB. 2017. Key Indicators for Asia and the Pacific 2017. Manila. Dari 19 perekonomian dengan data kemiskinan perkotaan-perdesaan yang sudah didisagregasikan (berdasarkan survei pendapatan dan pengeluaran rumah tangga nasional 2010-2016 yang tersedia), proporsi penduduk yang hidup di bawah garis kemiskinan nasional selalu konsisten lebih tinggi di daerah perdesaan daripada daerah perkotaan. 
upah, dan kemiskinan pendapatan masih terus terjadi, terutama di rumah tangga yang kepala keluarganya perempuan. Ketimpangan yang makin besar dapat mengganggu ikatan sosial, membahayakan stabilitas sosial dan politik, serta menghambat prospek ekonomi kawasan ini.

9. Kemajuan teknologi. Kemajuan di beragam bidang-termasuk teknologi mobile dan digital, robotika, kecerdasan artifisial, internet of things, dan pencetakan 3D-akan mengubah secara dramatis bagaimana barang dan layanan diproduksi, didistribusikan, dikirimkan, dan dikonsumsi. Berbagai teknologi ini dapat memunculkan industri baru dan meningkatkan kehidupan masyarakat. Teknologi tersebut dapat membawa peningkatan bagi, antara lain, perancangan dan manajemen infrastruktur, perawatan kesehatan, pendidikan, inklusi keuangan, akuntabilitas pemerintah, dan partisipasi masyarakat sipil. Namun, ada kekhawatiran mengenai luasnya dan dalamnya dampak teknologi terhadap masyarakat, termasuk kemungkinan tersingkirnya tenaga kerja (Kotak). Untuk bersiap menghadapi peluang dampak buruk, pemerintah harus mengadaptasi pendidikan, pelatihan, dan sistem perlindungan sosialnya.
10. Risiko perubahan iklim dan bencana. Perubahan iklim dan bencana mengancam keberlanjutan pembangunan jangka panjang di kawasan ini. Dalam beberapa dekade terakhir, Asia dan Pasifik mengalami peningkatan besar dalam jumlah, intensitas, dan dampak peristiwa cuaca ekstrem, seperti siklon tropis, banjir, kekeringan, dan gelombang panas. Bahaya geofisik, termasuk gempa bumi dan tsunami, juga telah menyebabkan korban jiwa dan kerusakan ekonomi signifikan. Dari antara 10 negara di seluruh dunia yang diperkirakan memiliki risiko bencana tertinggi, tujuh adalah DMC ADB. ${ }^{10}$ Kawasan Pasifik terutama rentan karena kenaikan permukaan laut seperti yang diproyeksikan akan mengancam kelangsungan jangka panjang banyak pulau di kawasan itu. ${ }^{11}$

\section{Tekanan yang makin kuat terhadap lingkungan.} Masalah lingkungan penting yang dihadapi kawasan ini mencakup polusi udara, polusi air dan tekanan terhadap sumber daya air, sampah di laut dan di sepanjang pantai serta daerah pesisir, manajemen sampah yang tidak memadai, deforestasi, degradasi lahan, dan hilangnya keanekaragaman hayati. Tekanan yang makin kuat terhadap lingkungan menjadi tantangan bagi keberlanjutan dan memperparah kerentanan yang sudah ada

\section{ASIA DAN PERKEMBANGAN TEKNOLOGI}

Perkembangan teknologi membuka peluang yang sangat luas bagi orang agar dapat saling terhubung, berdagang, dan mengakses layanan yang sebelumnya tidak tersedia. Teknologi baru telah memperluas platform untuk pendidikan (melalui pelajaran online dan ruang kelas virtual) serta perawatan kesehatan (seperti melalui telemedicine). Pasar digital dan layanan online menciptakan mekanisme perdagangan baru bagi usaha kecil-menengah, sedangkan teknologi seperti blockchain dapat merevolusi pembayaran dan logistik, serta berkontribusi terhadap inklusi keuangan. Kemajuan teknologi baru-baru ini telah menjadikan energi terbarukan lebih kompetitif terhadap energi dari bahan bakar fosil, sementara energi terbarukan yang bersifat lokal dalam bentuk jaringan telah memperluas akses terhadap listrik. Komunikasi modern kini dapat menjangkau daerah terpencil dengan biaya yang relatif rendah.

Perubahan teknologi mendorong pertumbuhan ekonomi dan meningkatkan standar kehidupan. Namun, ada pula kekhawatiran mengenai risiko hilangnya banyak pekerjaan akibat makin canggihnya ilmu robotika dan kecerdasan artifisial. Meskipun teknologi baru akan menciptakan lapangan kerja baru, termasuk dalam industri baru, pekerjaan tersebut mungkin memerlukan keterampilan yang belum dimiliki banyak pekerja, sehingga berkontribusi terhadap kemungkinan pengangguran dan/atau rendahnya pertumbuhan upah bagi pekerja yang kurang terampil. Tantangan bagi kawasan ini adalah memanfaatkan peluang yang dibawa teknologi, sambil bersiap menghadapi dan memitigasi risikonya.

Sumber: Asian Development Bank. 2018. Asian Development Outlook 2018. Manila.

10 Negara-negara tersebut adalah Bangladesh, Filipina, Kamboja, Kepulauan Solomon, Timor-Leste, Tonga, dan Vanuatu. L. Kirch et al. 2017. WorldRiskReport: Analysis and Prospects 2017. Berlin: Bündnis Entwicklung Hilft.

ADB. 2013. The Economics of Climate Change in the Pacific. Manila. 


\section{Gambar 3: Emisi Karbon Dioksida Menurut Kawasan}

\section{Miliar ton}

35

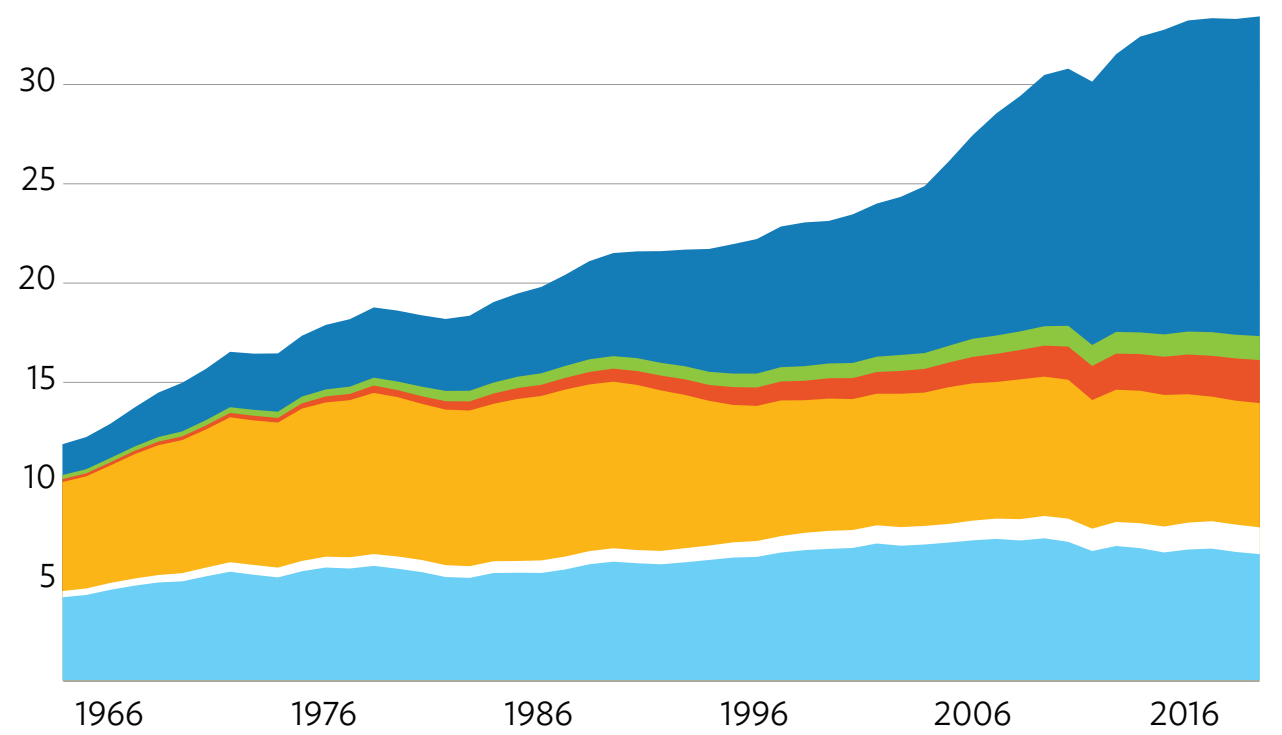

Asia dan Pasifik

Afrika

Timur Tengah

Eropa dan Eurasia

Amerika Selatan dan Tengah

Amerika Utara

Catatan: Mengacu pada emisi karbon dari konsumsi minyak, gas, dan batu bara untuk kegiatan yang berkaitan dengan pembakaran.

Sumber: BP. BP Statistical Review of World Energy 2017. London.

dalam kelompok miskin, yang sangat bergantung pada layanan ekosistem untuk penghidupan dan ketahanan pangan. Kawasan ini juga menghadapi kelangkaan air karena perubahan iklim, serta meningkatnya kebutuhan air akibat pertumbuhan penduduk dan ekonomi yang pesat. Pemahaman atas keamanan air-panganenergi sangat penting. Sekitar $70 \%$ dari sumber daya air di Asia digunakan untuk menumbuhkan makanan, dan air juga digunakan dalam produksi energi. Konservasi dan penghematan sumber daya melalui penggunaan teknologi baru dan kebijakan publik juga sangat penting.

12. Sasaran pembangunan yang ambisius. Sasaran Pembangunan Berkelanjutan (SDG), Kerangka Kerja
Sendai untuk Pengurangan Risiko Bencana (Sendai Framework for Disaster Risk Reduction), dan Agenda Aksi Addis Ababa (dengan fokus memanfaatkan miliaran dana bantuan pembangunan untuk memobilisasi triliunan) sedang membentuk agenda pembangunan internasional. Sasaran Pembangunan Berkelanjutan (SDG) mengajak semua negara untuk mempercepat upaya guna mengakhiri kemiskinan, melindungi bumi, dan memastikan bahwa semua orang menikmati kedamaian dan kemakmuran. ${ }^{12}$ Kesepakatan Paris menjabarkan rencana untuk mempertahankan pemanasan global di bawah 2 derajat Celsius. ${ }^{13}$ Mengingat besarnya jumlah penduduk Asia dan Pasifik, pemenuhan SDG penting dari segi kemiskinan, kelaparan, dan tidak

\footnotetext{
United Nations. Sustainable Development Goals. http://www.un.org/sustainabledevelopment/sustainable-development-goals.

Diadopsi dalam Konferensi Perubahan Iklim PBB ke-21 (COP21) di Paris, Prancis, pada Desember 2015.
} 


\section{Mengingat besarnya jumlah penduduk Asia dan Pasifik, pemenuhan Sasaran Pembangunan Berkelanjutan penting dari segi kemiskinan, kelaparan, dan tidak adanya akses ke layanan sosial akan sangat bergantung pada keberhasilan di kawasan ini. Kawasan ini juga berpeluang mengarahkan upaya global dalam mengurangi emisi gas rumah kaca (GHG) karena kawasan inilah yang menjadi sumber emisi GHG yang tumbuh paling cepat.}

adanya akses ke layanan sosial akan sangat bergantung pada keberhasilan di kawasan ini. ${ }^{14}$ Kawasan ini juga berpeluang mengarahkan upaya global dalam mengurangi emisi gas rumah kaca (greenhouse gas - GHG) karena kawasan inilah yang menjadi sumber emisi GHG yang tumbuh paling cepat, mencapai 48\% dari emisi karbon dioksida global di sektor energi pada 2016 (Gambar 3). ${ }^{15}$

13. Kemunculan mitra pembangunan yang baru. Jumlah aktor pembangunan kawasan dan global yang

14 Bank Dunia. PovcalNet. http://iresearch.worldbank.org/PovcalNet/ home.aspx (diakses 11 Oktober 2017); Economic and Social Commission for Asia and the Pacific, United Nations Environment Programme, et al. 2016. Transformations for Sustainable Development: Promoting Environmental Sustainability in Asia and the Pacific. http:// www.unescap.org/sites/default/files/Full\%20report.pdf; dan FAO, International Fund for Agricultural Development, UNICEF, WFP, dan WHO. 2017. The State of Food Security and Nutrition in the World 2017: Building Resilience for Peace and Food Security. Roma: FAO. Berdasarkan perkiraan terbaru, Asia dan Pasifik didiami oleh 43\% dari penduduk seluruh negara berkembang yang mengalami kemiskinan ekstrem (dengan menggunakan \$1,90/hari pada paritas daya beli 2011; negara berkembang mengacu pada semua negara berpenghasilan rendah dan menengah dalam basis data PovcalNet berdasarkan klasifikasi negara oleh Bank Dunia), 64\% dari penduduk dunia yang kekurangan gizi, 35\% dari penduduk dunia tanpa akses listrik, 42\% dari penduduk dunia tanpa akses ke air yang lebih baik, dan 63\% dari penduduk dunia tanpa akses sanitasi dasar.

15 BP PIc. BPStatistical Review of World Energy 2017. London. Emisi karbon hanya mengacu pada emisi dari konsumsi minyak, gas, dan batu bara untuk kegiatan yang berkaitan dengan pembakaran dan didasarkan pada faktor default emisi karbon dioksida untuk pembakaran yang terdaftar dalam investaris GHG nasional pada Intergovernmental Panel on Climate Change (IPCC. 2006. IPCC Guidelines for National Greenhouse Gas Inventories. Jepang). Angka emisi tersebut tidak memperhitungkan penangkapan karbon, sumber emisi karbon yang lain, atau emisi dari gas rumah kaca yang lain. Perkiraan untuk Asia didasarkan pengelompokan negara oleh BP.

\section{Gambar 4: Perkiraan Kebutuhan Investasi Infrastruktur Menurut Sektor, 2016-2030 (harga 2015)}

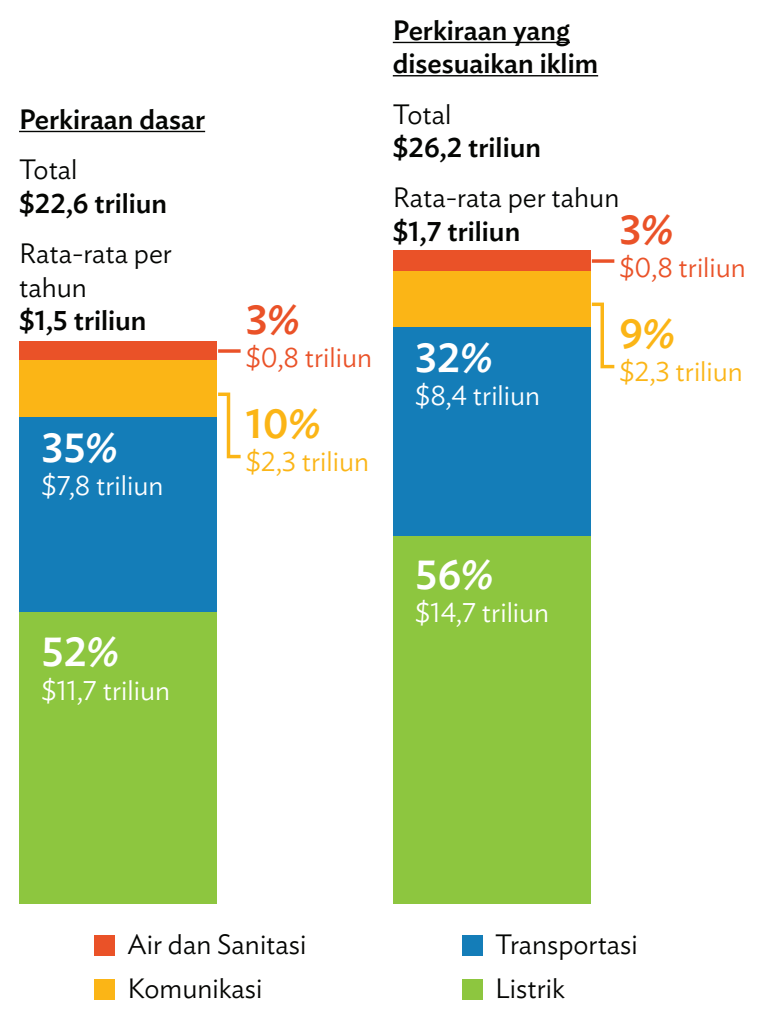

Catatan: Perkiraan kebutuhan untuk 45 negara berkembang anggota ADB.

Sumber: Asian Development Bank. 2017. Meeting Asia's Infrastructure Needs. Manila. 
beroperasi di Asia dan Pasifik telah bertambah signifikan selama sepuluh tahun terakhir. Ini mencakup munculnya organisasi masyarakat madani (CSO) dan donor nontradisional, seperti organisasi amal dan filantropis; serta pendirian bank pembangunan multilateral yang baru, seperti Asian Infrastructure Investment Bank dan New Development Bank. Mengingat makin pentingnya aliran masuk modal swasta, sektor swasta harus didorong untuk berperan lebih besar dalam pembangunan. Koordinasi dan pemanfaatan melalui kemitraan lintas batas nasional, kelembagaan, dan pemerintah-badan usaha menjadi sangat penting.

14. Dampak globalisasi. Integrasi erat dengan pasar global telah memberi manfaat bagi kawasan ini melalui peningkatan perdagangan dan aliran masuk modal eksternal. Rantai nilai global yang canggih sudah mulai muncul, sehingga menciptakan jaringan produksi yang melampaui perbatasan nasional. Didukung oleh reformasi yang berorientasi pasar dan stabilitas makroekonomi, keadaan ini adalah salah satu pendorong pertumbuhan terpenting di kawasan ini. Namun, integrasi dengan jaringan global juga menjadikan berbagai perekonomian terpapar pada guncangan eksternal. Efek resesi dan gejolak pasar modal akan tersebar lebih jauh dan lebih luas. Krisis keuangan global selama 20072009 memperlihatkan risiko aliran keuangan yang besar di tengah era pasar keuangan yang terhubung erat. Globalisasi dan teknologi juga berkaitan dengan melebarnya ketimpangan di banyak negara.

15. Defisit infrastruktur. Kawasan ini masih membutuhkan sumber daya yang cukup besar untuk mengisi defisit infrastruktur, terutama di daerah tertinggal. Lebih dari 400 juta penduduk Asia tidak memperoleh listrik, ${ }^{16}$ sekitar 300 juta tidak memiliki akses ke air bersih yang aman, dan 1,5 miliar kekurangan sanitasi dasar. ${ }^{17}$ Infrastruktur berkualitas buruk perlu segera mendapat perhatian. Di banyak negara, pemadaman listrik membatasi pertumbuhan ekonomi, sedangkan jaringan transportasi yang kurang terbangun membata- si aliran orang, barang, dan layanan. Rehabilitasi dan manajemen serta pemeliharaan aset infrastruktur secara lebih baik sangat penting. Berdasarkan perkiraan ADB terbaru, Asia dan Pasifik perlu menginvestasikan $\$ 26,2$ triliun dari 2016 sampai 2030, atau $\$ 1,7$ triliun per tahun bagi infrastruktur, demi mempertahankan momentum pertumbuhan, memberantas kemiskinan, dan menanggapi perubahan iklim (Gambar 4). Sektor swasta akan menjadi sumber pembiayaan yang sangat penting.

16. Urbanisasi yang pesat. Persentasi penduduk perkotaan di kawasan ini meningkat dari sekitar 20\% pada tahun 1950-an menjadi sekitar 48\% pada 2018. Pada 2030, penduduk perkotaan diproyeksikan akan naik menjadi 55\% atau sekitar 2,5 miliar orang yang tinggal di daerah perkotaan. ${ }^{18}$ Urbanisasi pesat menciptakan peluang sekaligus tantangan. Pergeseran penduduk dari daerah perdesaan ke perkotaan sering dikaitkan dengan peluang ekonomi, akses yang lebih baik terhadap layanan kesehatan dan pendidikan, serta kondisi hidup yang lebih baik. Namun, kota-kota di Asia dan Pasifik terus membesar dan makin rumit untuk dikelola. Degradasi lingkungan dan masih sangat minimnya infrastruktur perkotaan perlu dibenahi. Pada tahun 2014, terdapat 431 juta orang di Kawasan Asia yang Sedang Berkembang yang tinggal di kawasan kumuh-setara dengan 58\% dari penduduk kawasan kumuh seluruh dunia. ${ }^{19}$ Kota-kota, terutama yang berada di dataran rendah di sepanjang pesisir pantai, makin rentan terhadap bencana alam.

17. Perubahan demografi. Usia harapan hidup yang lebih tinggi dan menurunnya tingkat fertilitas menyebabkan beberapa DMC menua dengan cepat. Perserikatan Bangsa-Bangsa memproyeksikan bahwa populasi lansia (penduduk berusia 65 tahun ke atas) di Asia dan Pasifik akan naik dari sekitar 334 juta pada 2016 menjadi sekitar 870 juta pada 2050. Selama periode ini, persentase penduduk lansia akan meningkat dari $8,1 \%$ menjadi 18,1\% dari jumlah pen-

16 Economic and Social Commission for Asia and the Pacific, ADB, dan Program Pembangunan PBB (UNDP). 2017. Eradicating Poverty and Promoting Prosperity in a Changing Asia-Pacific. Bangkok.

17 UNICEF dan WHO. 2015. Progress on Sanitation and Drinking Water: 2015 Update and MDG Assessment. Jenewa.

18 United Nations Department of Economic and Social Affairs, Population Division. 2018. World Urbanization Prospects: The 2018 Revision. New York.

19 Bank Dunia. Indikator Pembangunan Dunia (WDI). http://databank.worldbank.org/data/reports.aspx? source=world-development-indicators (diakses 19 Februari 2018). 
duduk total. ${ }^{20}$ Bertambahnya persentase lansia relatif terhadap penduduk yang bekerja menimbulkan tantangan fiskal bagi pemerintah, seperti menurunnya pendapatan pajak dan meningkatnya pengeluaran perawatan kesehatan. Penduduk lansia di DMC $A D B$, terutama perempuan, sering kali tidak memiliki pensiun atau asuransi kesehatan yang memadai. Sebaliknya, beberapa DMC memiliki penduduk usia muda yang terus bertambah. Terdapat 2 miliar individu berusia di bawah 30 tahun yang tinggal di Asia dan Pasifik, mewakili 54\% dari jumlah penduduk muda global. ${ }^{21}$ Demografi yang menguntungkan atau dividen demografi sering berkaitan dengan pembangunan ekonomi dan kemajuan sosial yang kuat, tetapi hal ini bergantung pada kemampuan DMC untuk menawarkan pekerjaan berkualitas dan memaksimalkan produktivitas pekerja. ${ }^{22}$

18. Tata kelola dan kapasitas kelembagaan. Mengelola tantangan dan peluang yang ditimbulkan oleh perubahan keadaan di kawasan ini memerlukan tata kelola yang efektif. Namun, banyak negara di kawasan ini masih menghadapi masalah tata kelola, termasuk buruknya layanan publik, lemahnya lembaga pemerintah, dan korupsi. Reformasi tata kelola untuk melawan korupsi dan memperkuat pelayanan masyarakat profesional, kualitas regulasi, dan aturan hukum, diperlukan guna mempertahankan momentum pembangunan dan memastikan manfaat pertumbuhan sudah dibagikan secara adil dan meluas.

United Nations Department of Economic and Social Affairs, Population Division. 2017. World Population Prospects: The 2017 Revision. New York. 21 United Nations Department of Economic and Social Affairs, Population Division. 2017. World Population Prospects: The 2017 Revision. New York.

22 D. Park, S-H. Lee, dan A. Mason, editor. 2011. Aging, Economic Growth, and Old-Age Security in Asia. Manila: ADB / Cheltenham, Inggris; dan Northampton, Massachusetts, Amerika Serikat: Edward Elgar Publishing. 


\section{VISI DAN NILAI TAMBAHADB}

19. Visi ADB untuk Asia dan Pasifik. Seiring transformasi kawasan ini dan berubahnya kebutuhan dan tantangan DMC, ADB pun perlu berubah. Dengan Strategi 2030, ADB akan melanjutkan upayanya memberantas kemiskinan ekstrem, mengingat belum selesainya agenda kemiskinan di kawasan ini, dan memperluas visinya untuk mencapai Asia dan Pasifik yang makmur, inklusif, tangguh, dan berkelanjutan. ADB akan membantu kawasan ini berkembang dengan mempertahankan

\section{ADB akan melanjutkan upayanya memberantas kemiskinan ekstrem, mengingat belum selesainya agenda kemiskinan di kawasan ini, dan memperluas visinya untuk mencapai Asia dan Pasifik yang makmur, inklusif, tangguh, dan berkelanjutan.}

\section{ADB akan terus memprioritaskan dukungan bagi negara-negara termiskin dan paling rentan di kawasan ini.}

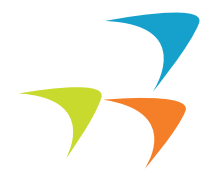

pertumbuhan ekonomi berkualitas dan menciptakan lapangan kerja. ADB akan mendorong inklusi untuk memastikan bahwa pencapaian ekonomi sudah terbagi secara luas. ADB akan mendukung ketangguhan dan keberlanjutan di berbagai negara, terutama bagi penduduk yang rentan, dan mendorong $\mathrm{RCl}$ (Gambar 5). ADB akan terus memprioritaskan dukungan bagi negara-negara termiskin dan paling rentan di kawasan ini.

20. Mencapai komitmen global. Aspirasi ADB bagi Asia dan Pasifik selaras dengan sejumlah komitmen global utama yang dukungannya telah diikrarkan oleh DMC dan ADB-Sasaran Pembangunan Berkelanjutan (SDG) dan agenda Pembiayaan Pembangunan (Financing for Development) yang berkaitan, Kesepakatan Paris tentang perubahan iklim, dan Kerangka Kerja Sendai untuk Pengurangan Risiko Bencana. Operasi ADB di masa mendatang akan dirancang untuk membantu memenuhi sasaran dan target tersebut. ${ }^{23}$ ADB juga akan berperan penting dalam mendukung agenda $\mathrm{G} 20$ mengenai pembangunan infrastruktur sebagai sumber pertumbuhan global.

\section{Mendorong pembangunan berkelanjutan melalui intervensi di sektor sosial dan infrastruktur.} Meskipun ADB akan memperluas intervensi di sektor sosial, seperti pendidikan, kesehatan, dan perlindungan sosial, ADB akan tetap memberi prioritas penting bagi infrastruktur dalam operasinya. Infrastruktur berperan vital dalam pertumbuhan ekonomi dan pembangunan sosial. Investasi infrastruktur berkelanjutan akan menjadi penting demi mencapai komitmen global untuk mengatasi perubahan iklim dan memperkuat manajemen risiko bencana. ${ }^{24}$ Infrastruktur juga membantu

23 Visi ADB akan Asia dan Pasifik yang makmur, inklusif, tangguh, dan berkelanjutan selaras dengan SDG dan Agenda Pembangunan 2030. Sasaran penting bagi operasi ADB mencakup kemiskinan nol (SDG 1); kesetaraan gender (SDG 5); energi yang terjangkau dan bersih (SDG 7); pekerjaan yang layak dan pertumbuhan ekonomi (SDG 8); industri, inovasi, dan infrastruktur (SDG 9); pengurangan ketimpangan (SDG 10); dan tindakan iklim (SDG 13). Operasi ADB juga akan berkontribusi terhadap kelaparan nol (SDG 2), kesehatan yang baik dan kesejahteraan (SDG 3), pendidikan berkualitas (SDG 4), air bersih dan sanitasi (SDG 6), kota dan komunitas berkelanjutan (SDG 11), konsumsi berkelanjutan (SDG 12), serta perdamaian dan keadilan, lembaga yang kuat (SDG 16). Dukungan ADB untuk konservasi dan pemulihan modal alami (paragraf 52) akan berkontribusi bagi kehidupan di bawah air (SDG 14) dan kehidupan di darat (SDG 15). Operasi ADB juga akan berperan penting dalam mendorong kemitraan untuk mencapai SDG (SDG 17).

24 Infrastruktur berkelanjutan adalah infrastruktur yang dirancang, dibangun, dan dioperasikan agar tahan lama, berkeadilan sosial, dan layak dari segi ekonomi dan lingkungan. ADB. 2018. Annual Report 2017. Manila. 
memenuhi meningkatnya kebutuhan akan pendidikan, perawatan kesehatan, dan layanan sosial berkualitas lainnya; mengatasi tantangan yang mulai muncul seperti penuaan; dan mengembangkan keterampilan untuk beradaptasi dengan teknologi baru. ADB akan mendorong investasi infrastruktur berkualitas yang ramah lingkungan, berkelanjutan, tangguh, dan inklusif. Melalui operasi infrastrukturnya, ADB akan berupaya meningkatkan akses kelompok miskin, perempuan, dan yang rentan (termasuk lansia dan difabel) terhadap layanan energi, transportasi, air bersih, dan sanitasi dasar. ADB akan mendorong konektivitas di dalam dan di antara negara untuk memacu pertumbuhan ekonomi dan makin mengurangi kemiskinan.

22. Nilai tambah ADB. ADB akan tetap menjadi mitra pembangunan tepercaya, yang menyampaikan operasi berkualitas tertinggi. ADB memberi perspektif kawasan unik, yang dikombinasikan dengan ke- beradaan negara yang kuat dan hubungan klien yang terbangun melalui pelibatan selama bertahun-tahun. Dukungan ADB akan menggabungkan pembiayaan, pengetahuan, dan kemitraan untuk memaksimalkan dampak pembangunan bagi para kliennya. Sebagai penyedia pembiayaan yang dapat diandalkan dan pengkatalisasi pembiayaan, ADB akan menyediakan pembiayaan sendiri sambil memobilisasi dan mengkatalisasi dana dari sumber yang lain. Sebagai penyedia pengetahuan, ADB akan berfokus pada nilai praktis yang sesuai kondisi setempat, mengidentifikasi pembelajaran, dan mereplikasi praktik baik (termasuk transfer teknologi, perlindungan lingkungan dan sosial, serta standar fidusia) ke seluruh kawasan ini dan lebih luas lagi. Sebagai penggagas kemitraan, ADB akan mendorong dialog dan kerja sama di antara mitra dan pemangku kepentingan yang beragam, termasuk lembaga keuangan internasional, mitra pembangunan bilateral, organisasi amal dan filantropis, CSO,

\section{Gambar 5: Visi, Nilai Tambah, dan Prinsip-Prinsip Pemandu ADB}

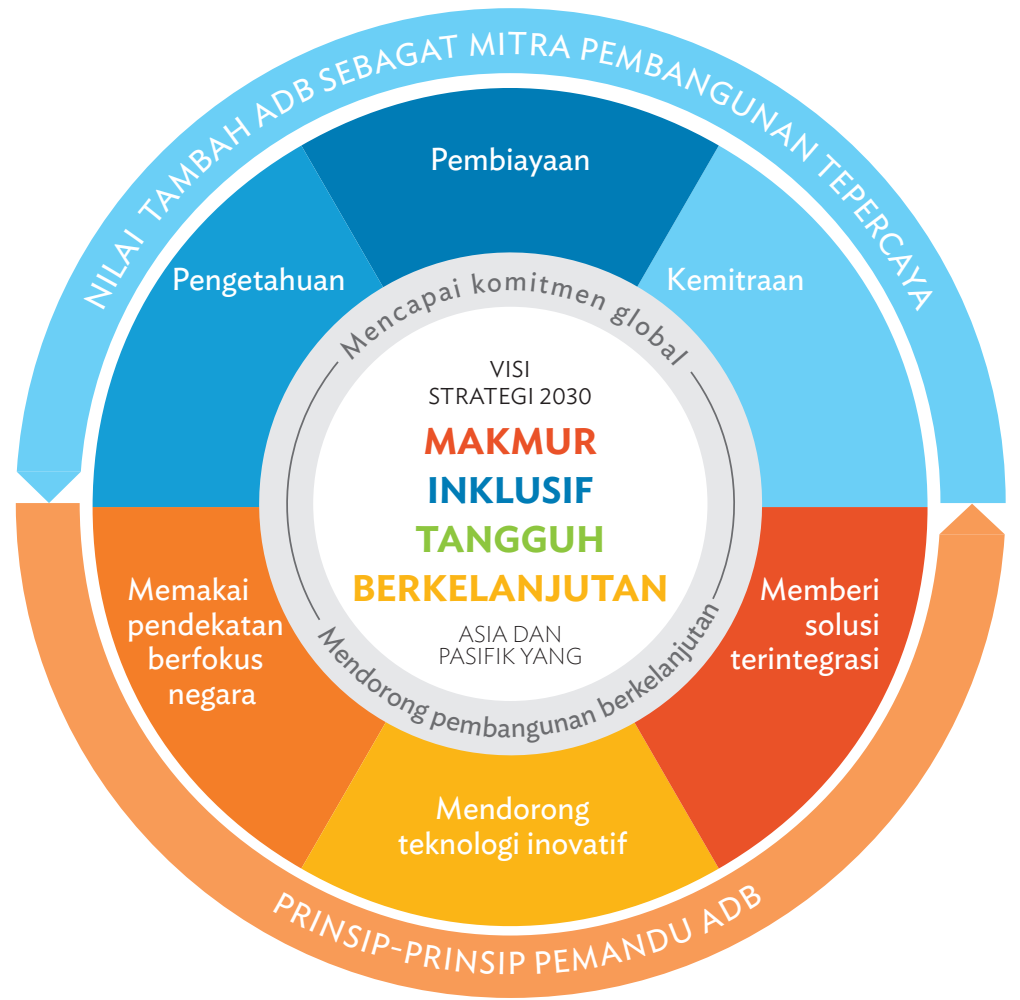

ADB = Asian Development Bank.

Sumber: Asian Development Bank. 
dan sektor swasta. Sejalan dengan upaya G20 untuk memperkuat tata kelola keuangan global, kerja sama dengan Dana Moneter Internasional (International Monetary Fund - IMF) dan bank pembangunan mul- tilateral lainnya akan berupaya memaksimalkan dampak dari sistem lembaga keuangan internasional secara keseluruhan. ADB juga akan meningkatkan fungsinya sebagai pengembang proyek. 


\section{PRINSIP-PRINSIP PEMANDU OPERASI ADB

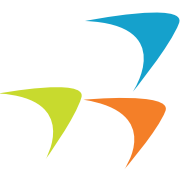

23. Menggunakan pendekatan berfokus negara. Agenda pembangunan global yang ambisius harus disesuaikan dengan keadaan setempat yang spesifik. Berbagai DMC memiliki kebutuhan, kekuatan kelembagaan, dan ketersediaan sumber daya yang berbeda-beda secara signifikan, termasuk di antara negara dengan pendapatan per kapita yang serupa. ADB akan menyesuaikan pendekatan untuk memenuhi kebutuhan basis klien yang berbeda-beda tersebut. Dengan Strategi 2030, ADB akan meningkatkan dialog kebijakan dan pekerjaan analisis, termasuk upaya mencapai target SDG dan Kesepakatan Paris pada tingkat negara. Strategi kemitraan negara (CPS) akan terus menjadi platform utama dalam menetapkan fokus operasional ADB di suatu negara-dengan DMC sebagai pendorong pembangunannya sendiri dan ADB sebagai mitra penyedia solusi yang disesuaikan bagi kebutuhan dan tantangan pembangunan. ADB akan bertindak selektif di tingkat negara untuk memastikan agar penggunaan sumber dayanya tidak terlalu dipaksakan, sambil mempertahankan kemampuan untuk fleksi-

\section{Berbagai DMC memiliki kebutuhan, kekuatan kelembagaan, dan ketersediaan sumber daya yang berbeda- beda secara signifikan, termasuk di antara negara dengan pendapatan per kapita yang serupa. ADB akan menyesuaikan pendekatan untuk memenuhi kebutuhan basis klien yang berbeda-beda tersebut.}

bel. Keterlibatan ADB dalam tema atau sektor spesifik di sebuah negara akan didasarkan pada keunggulan komparatif dibandingkan dengan mitra pembangunan yang lain, kebutuhan negara secara khusus, dan potensi memberi nilai tambah dalam batas kapasitas dan sumber daya ADB. Melanjutkan rekam jejak kerja samanya yang kuat, $A D B$ akan makin memperkuat koordinasi dan kemitraan dengan lembaga keuangan internasional yang lain, mitra bilateral, CSO, dan sektor swasta di tingkat negara.

24. Mendorong teknologi inovatif. ADB akan proaktif mencari cara untuk mendorong penggunaan teknologi maju dalam kegiatan operasional dan mendukung peningkatan kapasitas bagi DMC. ADB akan mendukung negara dalam mengembangkan kebijakan dan meningkatkan lingkungan regulasi bagi ekonomi digital, memperluas konektivitas internet, dan berinvestasi dalam perangkat keras dan perangkat lunak. Dalam operasi infrastruktur, ADB akan mendorong teknologi maju yang mengurangi biaya siklus hidup dan meningkatkan durabilitas, meningkatkan efisiensi dan kualitas layanan, serta meminimalkan dampak lingkungan dan sosial yang negatif. ADB akan mengarusutamakan penggunaan teknologi maju dengan melaksanakan uji coba, memperkuat rancangan proyek, menekankan kualitas dalam pengadaan, dan memobilisasi pakar di bidang yang bersangkutan.

25. Menyampaikan solusi terintegrasi. ADB akan menawarkan solusi terintegrasi yang menggabungkan keahlian dari berbagai sektor dan tema. Berbagai solusi tersebut akan disampaikan melalui campuran operasi sektor publik dan swasta yang sesuai, yang paling cocok untuk kebutuhan spesifik di lapangan. ADB akan memperkokoh pendekatan Satu ADB-dengan staf sektor publik dan swasta yang bekerja secara sistematis untuk mengevaluasi potensi solusi sektor swasta—baik dari segi ketentuan penyediaan layanan maupun pembiayaan, dan akan menggunakan solusi tersebut manakala memungkinkan. CPS akan menjadi platform utama untuk menyampaikan solusi terintegrasi tersebut melalui pelibatan negara yang lebih mendalam dan kantor perwakilan yang lebih kuat. 


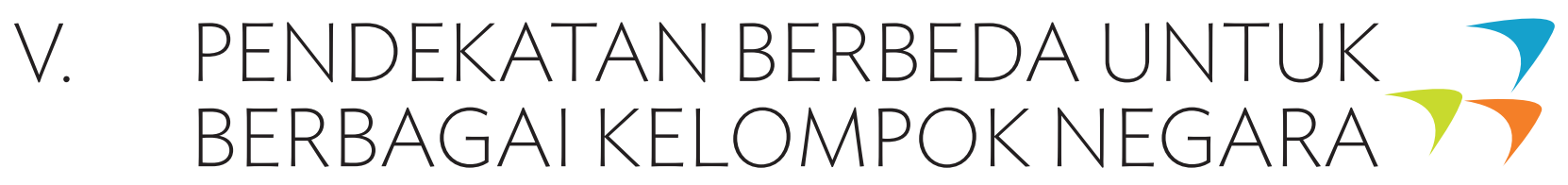

26. Kondisi yang rapuh dan terdampak konflik. Negara-negara dalam kondisi yang rapuh dan terdampak konflik (fragile and conflict-affected situation - FCAS) menghadapi derajat kerapuhan yang tinggi dan sangat membutuhkan penguatan kelembagaan. ${ }^{25}$ Di negara-negara yang ditandai sebagai kondisi yang rapuh dan terdampak konflik (FCAS), dukungan ADB akan difokuskan pada peningkatan kelembagaan dan reformasi tata kelola, infrastruktur penting dan layanan sosial, serta bantuan sosial yang tepat sasaran. ADB akan mendukung upaya membangun ketangguhan, mengatasi sumber penyebab konflik, serta mendorong rekonsiliasi dan rekonstruksi. ADB akan meningkatkan keterampilan staf, menyesuaikan proses pelaksanaan dengan kenyataan di lapangan, serta memperkuat kerja sama dengan mitra pembangunan yang lain dan CSO untuk menjadikan CPS dan operasi ADB peka terhadap kondisi yang rapuh dan konflik. ADB akan memperkuat sumber daya untuk mengakomodasi tambahan biaya bagi pemrosesan dan pengawasan akibat kebutuhan keamanan dan kebutuhan lainnya yang terkait, serta untuk memastikan bahwa negara yang berhasil mengatasi konflik dan kondisi yang rapuh tidak terjerumus kembali dalam kondisi tersebut.

\section{Negara pulau kecil yang berkembang. Piagam} ADB memberi perhatian khusus bagi kebutuhan negara anggota yang lebih kecil atau kurang berkembang di kawasan ini. ${ }^{26}$ Negara pulau kecil yang berkembang (small island developing states - SIDS) terutama rentan terhadap perubahan iklim dan guncangan akibat bencana. keanekaragaman hayati dan zona pesisirnya yang kaya sangat rentan terhadap degradasi lingkungan. Perekonomian negara-negara ini sering terkendala oleh pasar domestik yang kecil, biaya tinggi untuk berusaha, dan tantangan konektivitas ke pasar kawasan dan internasional. Negara pulau kecil yang berkembang (SIDS) menghadapi keterbatasan besar dari segi kapasitas kelembagaan, sama seperti negara FCAS. Karena itu, banyak DMC ADB berupa negara pulau kecil yang berkembang diklasifikasikan sebagai FCAS, padahal konflik bukanlah risiko yang dominan. ${ }^{27}$ Negara-negara ini juga menghadapi kerentanan tinggi terhadap guncangan ekonomi, yang makin diperparah akibat kecilnya basis ekonomi, terbatasnya ekspor, dan ketergantungan tinggi pada pemasok asing untuk banyak barang dan layanan penting. Dengan Strategi 2030, ADB akan memperluas fokusnya pada SIDS (termasuk SIDS yang belum dikategorikan sebagai FCAS). ${ }^{28}$ Dukungan ADB akan difokuskan pada adaptasi perubahan iklim, kelestarian lingkungan, dan manajemen risiko bencana. ADB akan makin memperkuat konektivitas dan akses di bidangbidang seperti teknologi informasi dan komunikasi (information and communication technology - ICT), serta transportasi laut dan darat; dan menekankan penguatan kelembagaan untuk mendukung upaya negara-negara dalam mengelola risiko keuangan dan ekonomi. ADB akan membantu SIDS meningkatkan lingkungan usaha, mereformasi Badan Usaha Milik Negara (BUMN), meningkatkan kerja sama pemerintah-badan usaha (PPP) guna menurunkan biaya berusaha, memperkuat kualitas penyampaian layanan publik, dan mendorong pertumbuhan yang dipimpin sektor swasta. ADB akan terus menyesuaikan proses bisnisnya untuk memenuhi kebutuhan dan mengatasi kendala di negara pulau kecil, memperkuat peningkatan kapasitas teknis langsung dan dukungan pelaksanaan, serupa dengan hal yang kini sedang dilakukan oleh Rencana Aksi Peningkatan Proyek Pasifik (Pacific

\footnotetext{
25 ADB mengklasifikasikan suatu negara sebagai FCAS dengan menggunakan pendekatan harmonisasi bersama antara Bank Pembangunan Afrika, ADB, dan Bank Dunia. Rencana operasional ADB bagi FCAS memungkinkan ADB untuk memasukkan negara lainnya yang memperlihatkan kondisi rapuh serupa atau memiliki daerah yang keadaannya rapuh atau berkonflik, dalam konsultasi dengan negara bersangkutan. Sampai dengan Juni 2018 , belum ada tambahan negara FCAS yang teridentifikasi melalui proses ini. ADB. 2013. Operational Plan for Enhancing ADB's Effectiveness in Fragile and Conflict-Affected Situations. Manila.

26 ADB. 1966. Agreement Establishing the Asian Development Bank. Manila.

27 Klasifikasi SIDS oleh PBB. Sampai dengan Mei 2018, dari sembilan DMC ADB yang diklasifikasikan sebagai FCAS, tujuh di antaranya adalah SIDS. ADB akan meninjau dan menajamkan definisi FCAS dan SIDS secara berkala agar selaras dengan mitra pembangunan lainnya.

28 SIDS yang saat ini bukan FCAS adalah Kepulauan Cook, Fiji, Maladewa, Palau, Samoa, Timor-Leste, Tonga, dan Vanuatu.
} 


\section{Konsisten dengan visinya untuk mendorong inklusi, ADB akan terus memprioritaskan dukungan bagi negara-negara termiskin dan paling rentan di kawasan ini, termasuk juga UMIC.}

Project Improvement Action Plan), serta lebih memperkuat kehadiran di lapangan. ${ }^{29}$

28. Negara berpenghasilan rendah dan menengah-bawah. Negara berpenghasilan rendah dan menengah-bawah menghadapi beragam tantangan dalam mempertahankan dan mempercepat laju kemajuan. ADB akan memberi pembiayaan jangka panjang yang dapat diprediksi dan bernilai besar untuk mendukung negara berpenghasilan rendah dan menengah-bawah, serta akan menjadi mitra tepercaya dalam mendukung reformasi struktural dan sistemik. Fokus ADB akan mencakup infrastruktur ramah lingkungan dan inklusif, layanan sosial dan perlindungan sosial, urbanisasi berkelanjutan, transformasi struktural untuk meningkatkan produktivitas dan daya saing, reformasi sektor publik, pengembangan sektor swasta, dan mobilisasi sumber daya domestik. ADB juga akan mendukung reformasi BUMN dan meningkatkan operasi sektor swasta dengan menarik investor swasta dan mengundang pembiayaan bersama yang bersifat komersial. Pertimbangan khusus akan diberikan kepada negara-negara yang menghadapi kerentanan karena geografinya, seperti kondisi berbukit-bukit dan pegunungan. Negara tersebut menghadapi masalah besar akibat perubahan iklim.

29. Negara berpenghasilan menengah-atas. Banyak negara berpenghasilan menengah-atas (upper middle-income country - UMIC) yang telah meningkatkan standar kehidupannya, tetapi berbeda-beda dalam pembangunan ekonomi, tantangan sosial, akses ke pasar modal, dan kekuatan lembaganya. ADB akan berfokus pada bidang-bidang yang dapat diberi nilai tambah terbesar dengan membantu negara tersebut meningkatkan akses ke pasar modal, memperkuat kelembagaan, dan mengembangkan proyek perconto- han. ADB akan memperluas operasi sektor swastanya, termasuk PPP, memberi dukungan terarah bagi reformasi sektor keuangan dan BUMN, serta meningkatkan ketangguhan negara terhadap guncangan. Berbagi pengalaman, praktik terbaik, dan inovasi akan menjadi elemen yang makin penting dalam keterlibatan $A D B$ dengan negara berpenghasilan menengah-atas (UMIC) dibandingkan sekadar volume pinjaman, terutama di bidang yang sangat penting seperti barang publik untuk kawasan, perubahan iklim, urbanisasi, $\mathrm{RCI}$, dan masalah sosial yang mulai muncul seperti penuaan. ADB akan memfasilitasi kerja sama di antara anggotanya dari negara berkembang untuk berbagi pengetahuan tersebut.

30. Kantung-kantung kemiskinan dan kerentanan di tingkat daerah. Konsisten dengan visinya untuk mendorong inklusi, ADB akan memprioritaskan dukungan bagi daerah tertinggal, serta kantung kemiskinan di DMC, termasuk UMIC. Masih ada daerah atau segmen penduduk yang mengalami kemiskinan persisten, yang sering disebabkan oleh kondisi rapuh dan konflik di tingkat daerah. ADB akan menerapkan pendekatan yang tepat sasaran untuk mengatasi kebutuhan tertentu di bidang-bidang ini, termasuk melalui bantuan teknis (TA) tambahan dan proses bisnis yang disederhanakan.

31. Kelulusan. ADB akan terus menerapkan kebijakan kelulusannya saat ini, sambil meninjau efektivitas kebijakan tersebut. ${ }^{30}$ Kelulusan dari bantuan reguler ADB akan melibatkan konsultasi mendalam dengan negara tersebut, termasuk analisis dan penilaian elemen penting kebijakan kelulusan. Selama periode transisi, dukungan ADB akan difokuskan terutama pada penguatan kebijakan dan lembaga yang diperlukan untuk kelulusan berkelanjutan, dukungan bagi barang publik untuk dunia

29 ADB. 2016. Pacific Approach, 2016-2020. Manila.

30 ADB. 1998. A Graduation Policy for the Bank's DMCs. Manila; dan ADB. 2008. Review of the 1998 Graduation Policy of the Asian Development Bank. Manila. Kebijakan kelulusan memberi kerangka kerja untuk klasifikasi negara berdasarkan pendapatan, ketersediaan aliran modal komersial dengan syarat yang wajar, dan tingkat pembangunan lembaga ekonomi dan sosial yang penting. 
dan kawasan, serta menciptakan pengetahuan. Berbagai prioritas tersebut akan tecermin dalam CPS.

\section{Memvariasikan ketentuan produk dan instru-}

men. ADB akan melaksanakan analisis terperinci dan berdiskusi dengan berbagai pemangku kepentingan mengenai peluang untuk lebih memvariasikan ketentuan pembiayaan. $\mathrm{ADB}$ akan mempertimbangkan untuk menggunakan berbagai variasi ketentuan pembiayaan guna melaksanakan pendekatan yang berbeda-beda, dan membantu memenuhi mandatnya serta memaksimalkan dampak pembangunan.

33. Pembiayaan konsesional. ADB akan mengarahkan pembiayaan konsesional dari sumber daya modal biasa (ordinary capital resources - OCR) yang bersifat konsesional dan dari hibah Dana Pembangunan Asia (Asian Development Fund - ADF) untuk mendukung DMC ADB yang paling miskin dan paling rentan. Banyak FCAS dan SIDS yang layak menerima bantuan konsesional. ADB juga akan mempertimbangkan dukungan tambahan bagi negara yang baru lulus dari bantuan konsesional. Penggunaan hibah Dana Pembangunan Asia (ADF) secara efisien di masa mendatang akan ditinjau melalui konsultasi bersama donor ADF. ADB juga akan terus memobilisasi sumber daya konsesional eksternal melalui dana perwalian (trust fund) yang dikelola ADB dan pembiayaan bersama dengan mitra bilateral dan multilateral (paragraf 87 dan 89). 


\section{PRIORITAS OPERASIONAL}

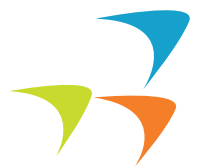

34. Guna mencapai visi Strategi 2030, ADB akan berfokus pada tujuh bidang prioritas operasional yang dijelaskan dalam paragraf 35-67. Bidang-bidang tersebut akan dijalankan sebagai prioritas yang berdiri sendiri atau digabungkan dengan prioritas lainnya. Sebagai contoh, pengurangan kemiskinan, inklusi yang lebih baik, kesetaraan gender, dan tata kelola akan diintegrasikan ke seluruh operasi ADB, jika sesuai. Dukungan ADB di bidang-bidang ini akan disampaikan melalui operasi sektor publik dan swasta, layanan konsultasi, dan dukungan pengetahuan.

\section{A. Mengatasi Kemiskinan yang Masih Ada dan Mengurangi Ketimpangan}

35. Meningkatkan penekanan pada perkembangan manusia dan inklusi sosial. Kemiskinan adalah tantangan yang bersifat multifaset. Meskipun Asia dan Pasifik telah mengalami kemajuan pesat dalam mengurangi kemiskinan pendapatan, masih banyak yang perlu dilakukan untuk mengatasi dimensi kemiskinan non-pendapatan dan kerentanan di daerah perdesaan dan perkotaan; mendorong inklusi dan pembangunan sosial, terutama untuk kelompok yang rentan; serta membangun ketangguhan. Guna memastikan bahwa semua anggota masyarakat dapat berpartisipasi dalam dan memperoleh manfaat dari pertumbuhan,
ADB akan membantu (i) mengurangi ketimpangan dalam mengakses peluang; (ii) memfasilitasi penciptaan pekerjaan berkualitas; dan (iii) memperluas dukungan bagi program pendidikan, perawatan kesehatan, dan perlindungan sosial.

36. Menghasilkan pekerjaan berkualitas. ADB akan membantu menghasilkan pekerjaan yang layak dan produktif guna mendukung pertumbuhan inklusif untuk semua. Mengingat penciptaan lapangan kerja terutama dilakukan oleh sektor swasta, ADB akan mendukung berbagai negara dalam meningkatkan lingkungan usaha bagi wirausaha dan perusahaan, termasuk usaha kecil dan menengah, serta usaha yang inklusif. ADB akan terus membantu meningkatkan layanan pengembangan usaha dan memperkuat sektor keuangan, termasuk keuangan inklusif. ADB juga akan membantu meningkatkan lingkungan kerja dengan mendukung standar tenaga kerja inti.

37. Meningkatkan pendidikan dan pelatihan. ADB akan terus mendukung pendidikan sebagai kebutuhan dasar masyarakat. ADB akan membantu DMC meningkatkan hasil pembelajaran bagi semua, meningkatkan kelayakan dipekerjakan dan kesiapan bekerja para lulusan, serta mendukung peluang pembelajaran dan pelatihan seumur hidup. ADB akan membantu penggunaan solusi teknologi informasi dan komunikasi (ICT) untuk

\section{TUJUH PRIORITAS OPERASIONAL STRATEGI 2030}

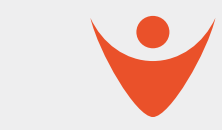

Mengatasi kemiskinan yang masih ada dan mengurangi ketimpangan

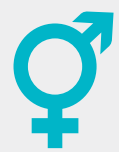

Mempercepat kemajuan dalam kesetaraan gender

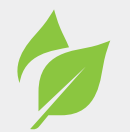

Menghadapi perubahan iklim, membangun ketangguhan terhadap iklim dan bencana, serta meningkatkan kelestarian lingkungan

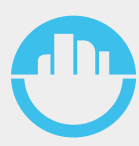

Menjadikan kota lebih

layak huni

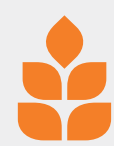

Mendorong pembangunan perdesaan dan ketahanan pangan
Memperkuat tata kelola dan kapasitas kelembagaan

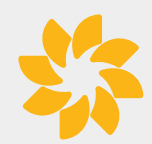

Mendorong kerja sama dan integrasi kawasan 
memberi pendidikan dan pelatihan berkualitas kepada siapa pun, di mana pun, dan kapan saja. ADB akan membantu memperkuat keterampilan dasar pelajar, termasuk literasi digital dan soft skill, serta pendidikan dan pelatihan teknik dan kejuruan. ADB akan membantu meningkatkan pendidikan sekunder dan tersier dengan fokus yang lebih besar pada ilmu pengetahuan, teknologi, ilmu teknik, dan matematika, terutama bagi pelajar perempuan. ADB akan mendorong kaitan yang lebih kuat dengan industri dan mendukung pembelajaran seumur hidup dan program pelatihan kembali guna memastikan bahwa pekerja yang berada di tengah jenjang karier dan pekerja yang lebih tua dapat tetap produktif.

38. Mencapai kesehatan yang lebih baik untuk semua. $A D B$ akan terus mendukung DMC dalam mengupayakan cakupan kesehatan universal dengan meningkatkan kualitas dan cakupan layanan perawatan kesehatan pemerintah dan swasta. ADB akan mendukung reformasi pembiayaan kesehatan, termasuk sistem asuransi kesehatan guna meningkatkan akses ke layanan perawatan kesehatan berkualitas dan mengurangi biaya yang harus dikeluarkan sendiri oleh kelompok miskin. ADB akan berupaya mengoptimalkan manfaat kesehatan tak langsung dengan memanfaatkan sinergi portofolionya dalam transportasi (keamanan jalan), perkotaan (kota yang sehat), air (keamanan air), sanitasi (penyakit menular), dan energi (rendah karbon dan pengurangan polusi). ADB akan membantu DMC dalam mengelola makin tingginya beban penyakit tidak menular dan perawatan lansia dengan cara yang hemat biaya dan berkelanjutan. ADB juga akan mendorong penggunaan lebih besar sistem penyampaian layanan kesehatan yang inovatif dan cerdas.

39. Memastikan perlindungan sosial bagi orangorang yang membutuhkan. ADB akan terus bekerja sama dengan DMC untuk memperkuat sistem perlindungan sosial dan penyampaian layanan. ADB akan berfokus pada bantuan sosial dengan menyempurnakan rancangan dan penyampaian program transfer sosial, seperti bantuan tunai bersyarat, asuransi sosial seperti pensiun dan asuransi kesehatan, dan program pasar tenaga kerja untuk mendukung pengembangan keter- ampilan yang relevan dengan pekerjaan dan pelatihan kembali pekerja. Elemen perlindungan sosial akan diintegrasikan ke dalam proyek-proyek di sektor pendidikan (beasiswa, termasuk bagi anak perempuan; makanan sekolah; dan pelatihan keterampilan); manajemen keuangan dan publik (asuransi sosial dan pensiun); kesehatan (asuransi kesehatan); dan perkotaan (usia, gender, dan infrastruktur ramah difabel).

\section{( B. Mempercepat Kemajuan dalam Kesetaraan Gender}

40. Meningkatkan dukungan bagi kesetaraan gender. ADB akan membantu mempercepat kemajuan kesetaraan gender di DMC melalui (i) operasi yang tepat sasaran untuk memberdayakan perempuan dan anak perempuan di bidang-bidang seperti pendidikan, kesehatan, inklusi keuangan, dan penciptaan lapangan kerja; (ii) pengarusutamaan gender yang secara langsung memperkecil kesenjangan gender atau memberi manfaat bagi perempuan dan anak perempuan, misalnya proyek jalan desa yang memberi perempuan akses ke peluang yang menghasilkan pendapatan dan dikombinasikan dengan komponen peningkatan kapasitas untuk membantu perempuan meningkatkan keterampilannya; dan (iii) operasi dengan beberapa elemen gender di dalamnya yang memasukkan sejumlah tindakan dalam perancangan dan pelaksanaan proyek dan program $A D B$, misalnya meningkatkan peluang lapangan kerja bagi perempuan selama konstruksi, operasi, dan pemeliharaan. ADB menyadari bahwa proyek-proyek yang tidak diklasifikasikan sebagai (i)-(iii) juga dapat berpengaruh positif terhadap kehidupan perempuan dan anak perempuan. Sebagai contoh, proyek pembangkit listrik mungkin tidak secara khusus menargetkan untuk memperkecil kesenjangan gender saat menyalurkan listrik ke jaringan; namun, perempuan akan memperoleh manfaat penggunaan listrik dari segi pengurangan kemiskinan waktu dan akses yang lebih baik ke peluang pekerjaan.

41. Target gender. Sampai dengan 2030, setidaknya $75 \%$ dari jumlah operasi yang sudah menjadi komitmen ADB (berdasarkan rata-rata bergerak 3 tahun, termasuk operasi sektor publik dan swasta) akan mendorong kesetaraan gender. ${ }^{31}$

31 Operasi yang diklasifikasikan sebagai (i) dan (ii) dalam paragraf 40 akan mencapai setidaknya 55\% dari jumlah keseluruhan operasi yang sudah menjadi komitmen ADB (berdasarkan rata-rata bergerak 3 tahun, termasuk operasi sektor publik dan swasta). 
42. Bidang fokus. Dukungan ADB akan difokuskan pada lima bidang: pemberdayaan ekonomi perempuan, kesetaraan gender dalam perkembangan manusia, kesetaraan gender dalam pengambilan keputusan dan kepemimpinan, pengurangan kemiskinan waktu bagi perempuan, dan ketangguhan perempuan terhadap guncangan eksternal.

43. Mendorong pemberdayaan ekonomi perempuan. ADB akan memberi perhatian yang lebih besar untuk menghasilkan peluang kerja dan wirausaha bagi perempuan. Proyek infrastruktur akan memaksimalkan akses perempuan ke pasar dan peluang untuk pekerjaan terampil. Melalui peningkatan program pendidikan dan pelatihan teknik dan kejuruan, ADB akan memungkinkan akses perempuan ke pekerjaan berkualitas di sektor nontradisional yang membayar lebih tinggi. $\mathrm{ADB}$ akan memperluas dukungan terintegrasi bagi wirausaha perempuan dan UKM yang dipimpin perempuan melalui akses yang lebih baik ke pembiayaan, adopsi teknologi baru, serta reformasi kebijakan dan kelembagaan.

44. Mengupayakan kesetaraan gender dalam perkembangan manusia. Proyek pendidikan akan dirancang untuk meningkatkan kesetaraan gender dalam tingkat penyelesaian sekolah, hasil pembelajaran, dan transisi dari sekolah ke bekerja. ADB akan mendukung anak perempuan dalam mengikuti pendidikan ilmu pengetahuan, teknologi, ilmu teknik, dan matematika. Operasi kesehatan dan perlindungan sosial akan menjawab kebutuhan perempuan dan anak perempuan dalam hal kesehatan reproduktif dan kebutuhan kesehatan lainnya yang belum terpenuhi, serta kekerasan berbasis gender. Layanan perawatan lansia akan dirancang untuk mempermudah tugas perawatan keluarga perempuan dan memenuhi beragam kebutuhan perempuan lansia.

45. Meningkatkan kesetaraan gender dalam pengambilan keputusan dan kepemimpinan. Operasi ADB dalam mendukung reformasi hukum, kelembagaan, dan tata kelola akan mengkaji langkah-langkah untuk mencabut aturan yang diskriminatif dari segi gender, meningkatkan partisipasi perempuan dalam alokasi dan pengambilan keputusan sumber daya publik, serta mendukung kepemimpinan di semua tingkat.
46. Mengurangi kemiskinan waktu perempuan. ADB akan berinvestasi pada layanan infrastruktur seperti air dan sanitasi, listrik perdesaan, jalan perdesaan, kompor bersih dan biogas, serta teknologi tanaman panen dan produksi pangan guna membantu mengurangi beban dan waktu yang dihabiskan dalam manajemen penghidupan, dan pekerjaan rumah tangga dan pengasuhan yang tidak dibayar. Keselamatan dan mobilitas perempuan akan dipertimbangkan dalam perancangan infrastruktur perkotaan dan perdesaan.

47. Memperkuat ketangguhan perempuan terhadap guncangan eksternal. ADB akan mendukung DMC dalam mengarusutamakan gender ke dalam operasi perubahan iklim dan manajemen risiko bencana, serta meningkatkan akses perempuan ke pekerjaan lingkungan, teknologi cerdas iklim, dan partisipasi dalam pengambilan keputusan yang berkaitan dengan iklim. Untuk melindungi perempuan dalam rumah tangga berpenghasilan rendah dan rentan terhadap krisis ekonomi, pangan, dan krisis lainnya, ADB akan menjalankan bantuan sosial yang tepat sasaran dan penganggaran publik yang tanggap-gender.

\section{Menghadapi Perubahan Iklim, Membangun Ketangguhan terhadap Iklim dan Bencana, serta Meningkatkan Kelestarian Lingkungan}

48. Meningkatkan dukungan untuk mengatasi perubahan iklim, risiko bencana, dan degradasi lingkungan. ADB akan memastikan bahwa perubahan iklim, risiko bencana, dan pertimbangan lingkungan sudah diarusutamakan sepenuhnya dalam strategi operasional; program negara; serta dalam dokumen perancangan, pelaksanaan, pemantauan, dan evaluasi proyek. ADB akan memfasilitasi akses DMC ke teknologi yang lebih bersih dan lebih cerdas, mendorong pertumbuhan ekonomi yang menjaga kelestarian lingkungan, serta terus menyaring proyek dengan ketat terhadap risiko yang berkaitan dengan iklim dan bencana.

49. Target operasi iklim. Melanjutkan kinerja yang kuat dalam mengintegrasikan mitigasi dan adaptasi perubahan iklim ke dalam rancangan proyek, 75\% dari jumlah operasi yang sudah menjadi komitmen ADB (berdasarkan rata-rata bergerak 3 tahun, termasuk 
operasi sektor publik dan swasta) akan mendukung mitigasi dan adaptasi perubahan iklim sampai dengan 2030. Pembiayaan iklim dari sumber daya ADB sendiri akan mencapai $\$ 80$ miliar secara kumulatif untuk periode 2019 sampai 2030.32

50. Mempercepat pembangunan rendah emisi gas rumah kaca. ADB akan meningkatkan dukungannya bagi mitigasi perubahan iklim dengan memprioritaskan investasi untuk energi yang rendah emisi gas rumah kaca (GHG), melaksanakan strategi transportasi berkelanjutan dan transportasi perkotaan, serta mendorong DMC agar beralih ke jalur pembangunan yang rendah emisi gas rumah kaca, sejalan dengan kontribusi per negara yang ditentukan menurut Kesepakatan Paris. ADB akan menjalankan langkah-langkah ini melalui penggunaan selektif pembiayaan konsesional, pelibatan sektor swasta yang lebih besar, dan dukungan untuk PPP yang inovatif. ADB juga akan memfasilitasi akses ke pembiayaan karbon melalui pasar karbon domestik dan/atau internasional sebagai insentif untuk investasi mitigasi.

51. Memastikan pendekatan menyeluruh untuk membangun ketangguhan iklim dan bencana. ADB akan mendukung DMC dalam mengembangkan pendekatan terintegrasi untuk beradaptasi terhadap perubahan iklim dan meningkatkan ketangguhan iklim dan bencana. Langkah-langkahnya akan mencakup manajemen penggunaan lahan yang peka risiko, manajemen risiko banjir terintegrasi, rancangan infrastruktur yang tangguh iklim dan bencana, diversifikasi penghidupan agar memperhitungkan faktor perubahan iklim jangka panjang, serta memperkuat sistem peringatan dini. ADB akan memberi bantuan tanggap bencana, termasuk dukungan untuk membangun kembali dengan lebih baik. ADB akan memperkuat kesiapsiagaan keuangan DMC guna menanggapi bencana melalui berbagai instrumen seperti pembiayaan berbasis kebijakan dan asuransi bencana. ${ }^{33}$ ADB juga akan mendukung integrasi adaptasi iklim dan manajemen risiko bencana ke dalam rencana dan anggaran pembangunan, pengembangan kapasitas terkait, dan akses pengetahuan dari DMC yang bersangkutan.
52. Memastikan kelestarian lingkungan. $A D B$ akan (i) membantu DMC dalam meningkatkan manajemen lingkungannya, termasuk upaya meningkatkan kualitas udara dan air; serta (ii) berinvestasi dalam konservasi dan restorasi modal alami. ADB akan memperkuat perencanaan dan perancangan proyek yang eko-sensitif untuk mencegah degradasi ekosistem dan memitigasi dampak polusi. ADB akan melaksanakan hal ini melalui beragam pendekatan, termasuk menggunakan pembayaran untuk layanan ekosistem, solusi berbasis alam (misalnya penanaman mangrove untuk melawan gelombang badai dan kenaikan permukaan laut), dan pendekatan yang dipimpin masyarakat.

53. Meningkatkan fokus pada keamanan airmakanan-energi. ADB akan mendukung DMC dalam memastikan keamanan pasokan air secara keseluruhan dengan memperdalam pemahaman mengenai kaitan dan pertimbangan untung rugi antara kebutuhan ketahanan pangan dengan ketahanan energi di tingkat proyek, sektor, dan negara. ADB akan meningkatkan dukungan bagi manajemen sumber daya air terintegrasi guna memenuhi kebutuhan air yang saling bersaing dengan cara yang adil, berkelanjutan, dan efisien. ADB juga akan membantu (i) meningkatkan praktik pertanian, termasuk penggunaan teknologi pemodelan iklim dan prakiraan cuaca yang dapat diandalkan; (ii) mendorong energi yang tidak intensif menggunakan air, seperti tenaga surya dan angin; serta (iii) mendorong pasokan air dan sanitasi yang pemakaian energinya efisien.

\section{Menjadikan Kota Lebih Layak Huni}

54. Memberi solusi terintegrasi. Guna membantu membangun kota layak huni yang ramah lingkungan, kompetitif, tangguh, dan inklusif, ADB akan menjalankan proyek lintas-bidang untuk mendorong kesehatan perkotaan, mobilitas perkotaan, kesetaraan gender, dan kelestarian lingkungan. Proyek-proyek ADB akan berfokus pada menjawab persoalan keamanan pasokan air dan konservasi lingkungan guna menyediakan layanan air, sanitasi, dan pembuangan sampah yang terjangkau, aman, dan efektif. ADB akan mendukung transportasi publik

\footnotetext{
Target-target ini didasarkan pada definisi dan metodologi yang telah disepakati oleh berbagai bank pembangunan multilateral.

33 ADB memberi pembiayaan bencana darurat melalui pinjaman berbasis kebijakan bagi Kepulauan Cook pada tahun 2016 dan kepada Samoa, Tonga, dan Tuvalu berdasarkan program ketangguhan bencana kawasan pada 2017.
} 
yang bersifat massal, seperti jalur kereta bawah tanah dan sistem bus yang terhubung ke jalur sepeda dan pedestrian sehingga orang-orang, termasuk lansia dan difabel, dapat berganti dari satu moda transportasi ke moda lainnya dengan mudah dan aman. ADB akan mendukung kota-kota dalam mengembangkan lembaga dan kebijakan yang tepat, serta lingkungan yang memungkinkan untuk menjadi lebih kompetitif dan produktif. Proyek yang dibiayai ADB akan ditujukan untuk mengedepankan lingkungan perkotaan yang aman dan sehat bagi semua penduduknya.

\section{Dukungan pendanaan bagi perkotaan. ADB akan} membantu kota-kota menggali sumber pendanaan baru dan memperbesar sumber yang ada, termasuk melalui pajak properti, tagihan utilitas, atau biaya administrasi, serta transfer antar-pemerintahan yang dapat diprediksi. ADB akan membantu pemerintah daerah dan utilitas dalam menerbitkan obligasi kota atau obligasi proyek, dan dalam menggali peluang Kerja Sama Pemerintah-Badan Usaha.

56. Meningkatkan perencanaan perkotaan yang inklusif dan partisipatif. $A D B$ akan mendukung manajemen kota dalam memprioritaskan investasi dan mengembangkan rencana perkotaan terintegrasi berdasarkan kebutuhan setempat. ADB akan mempertimbangkan kebutuhan dari semua orang yang tinggal, bekerja, dan belajar di kota-kota melalui proses partisipatif yang melibatkan dunia usaha, akademisi, dan CSO. ADB akan bermitra dengan pemangku kepentingan dan penyedia layanan guna meningkatkan rencana sektor, kelayakan kredit kelembagaan, perancangan dan penyampaian proyek, serta keberlanjutan layanan.

57. Meningkatkan ketangguhan iklim dan manajemen bencana. Untuk meningkatkan ketangguhan kota, ADB akan mendorong integrasi pertimbangan perubahan iklim dan risiko bencana ke dalam proses perencanaan perkotaan. ADB akan meningkatkan kapasitas untuk kesiapsiagaan bencana yang efektif dengan memperkuat sistem peringatan dini dan rencana tanggap darurat guna menghindari korban jiwa.

\section{E. Mendorong Pembangunan Perdesaan dan Ketahanan Pangan}

58. Meningkatkan konektivitas pasar dan kaitan ke rantai nilai pertanian. ADB akan berfokus pada jalan perdesaan, infrastruktur pasar, dan pusat logistik pertanian guna memungkinkan integrasi lebih banyak produsen, agribisnis, dan konsumen ke dalam sistem pangan nasional, kawasan, dan global. Mengurangi kerugian pascapanen dan mendorong nilai tambah pertanian akan membantu meningkatkan pendapatan perdesaan dan meningkatkan ketahanan pangan. ADB juga akan membantu DMC meningkatkan konektivitas dan mobilitas antara daerah perdesaan dengan perkotaan.

59. Meningkatkan produktivitas pertanian dan ketahanan pangan. ADB akan membantu DMC menambah produktivitas pertanian dan mengurangi kemiskinan dengan meningkatkan pendapatan tani dan nontani. ADB akan mengedepankan adopsi teknologi maju seperti penerapan satelit dan bantuan drone guna meningkatkan efisiensi irigasi dan memastikan bahwa sumber daya lahan dan air digunakan secara berkelanjutan. ADB akan mendorong penggunaan praktik-praktik pertanian yang cerdas iklim, termasuk varietas tanaman panen yang tahan banjir dan kekeringan, serta irigasi tetes. Dukungan ADB akan meningkatkan standar manajemen sumber daya alam melalui pelaksanaan proyek-proyek reklamasi tanah, reboisasi, dan manajemen daerah aliran sungai guna mengurangi erosi tanah dan meningkatkan keanekaragaman hayati.

60. Meningkatkan keamanan pangan. ADB akan membantu DMC merumuskan dan melaksanakan kebijakan dan standar keamanan pangan, membangun laboratorium pengendalian mutu, dan menggunakan ICT untuk meningkatkan keterlacakan dan pelacakan pangan. ADB akan mendukung pelatihan dan pendidikan, program penjangkauan masyarakat, dan kepatuhan sukarela yang melibatkan semua pemangku kepentingan-petani, industri, dan konsumen.

\section{F. Memperkuat Tata Kelola dan Kapasitas Kelembagaan}

61. Mendukung reformasi manajemen publik dan kestabilan keuangan. Tata kelola yang baik dan kapasitas kelembagaan yang kuat adalah dasar bagi pembangunan negara. ADB akan membantu DMC meningkatkan tata kelola dan menciptakan lingkungan yang memungkinkan pertumbuhan berkelanjutan dengan memperkuat kualitas dan kapasitas lembaga publik 
guna melaksanakan reformasi kebijakan dan mendorong pengembangan sektor swasta. Melalui pinjaman berbasis kebijakan (policy-based lending - PBL), pinjaman berbasis hasil, pinjaman proyek, dan bantuan teknis, ADB akan terus mendukung reformasi pengeluaran publik; pengumpulan pendapatan, termasuk sistem dan penegakan pajak; serta pasar modal. ADB akan mendukung upaya pemerintah untuk memberantas korupsi dan memperkuat kegiatan anti-pencucian uang. ADB juga akan membantu negara-negara untuk mematuhi prakarsa internasional mengenai transparansi pajak. ADB akan membantu negara-negara membangun ketangguhan dan menanggapi guncangan ekonomi secara tepat waktu, dalam kerja sama erat dengan mitra pembangunan seperti Dana Moneter Internasional (IMF).

62. Memperkuat penyampaian layanan. ADB akan mendorong penyampaian layanan publik yang efektif, tepat waktu, dan bebas dari korupsi guna mendukung akuntabilitas lebih besar atas layanan yang diberikan. ADB akan lebih memanfaatkan ICT untuk meningkatkan kualitas penyampaian layanan publik. ADB akan mendukung reformasi kebijakan, regulasi, dan yang berkaitan dengan tarif guna mendorong keberlanjutan keuangan dan operasi yang efektif, serta pemeliharaan infrastruktur dan layanan lainnya. ADB akan bekerja sama dengan BUMN dan entitas daerah yang mengemban porsi penyampaian layanan publik lebih besar guna meningkatkan kapasitas manajemen keuangan dan tata kelola internal, sehingga memungkinkan entitas tersebut mengakses pembiayaan dengan syarat dan ketentuan komersial.

63. Memperkuat kapasitas dan standar. ADB akan menegakkan perlindungan lingkungan dan sosial, taat pada standar pengadaan dan manajemen keuangan, dan melaksanakan langkah-langkah antikorupsi dalam semua proyek dan program ADB. ADB akan berkontribusi untuk mempertahankan dan meningkatkan standar pada komunitas pembangunan internasional. ADB akan membantu DMC melaksanakan reformasi dan membangun sistem negara di bidang-bidang tersebut. ADB juga akan terus membantu lembaga eksekutif dan pelaksana untuk memperkuat kapasitasnya dalam merencanakan, merancang, membiayai, dan melaksanakan proyek-proyek ADB, termasuk penerapan teknologi maju, pengurangan biaya siklus-hidup, penjam- inan kelayakan keuangan investasi, dan pemeliharaan aset infrastruktur.

\section{G. Mendorong Kerja Sama dan Integrasi Kawasan}

64. Meningkatkan konektivitas dan daya saing. ADB akan meningkatkan konektivitas di kawasan dan memperkuat daya saing DMC dengan mengatasi kebutuhan infrastruktur lintas batas. ADB akan mendukung dialog kebijakan dan koordinasi di antara DMC untuk mengubah koridor transportasi menjadi koridor perdagangan dan ekonomi. Kaitan transportasi multimoda dan konektivitas sektor energi akan diperkuat di seluruh subkawasan. Perhatian khusus akan diberikan bagi kebutuhan perekonomian negara pulau kecil dan negara yang terkurung daratan. Dukungan ADB akan memfasilitasi partisipasi DMC dalam rantai nilai kawasan dan global. Operasi RCl akan mengedepankan perdagangan pertanian dan pariwisata kawasan.

65. Mendorong barang publik untuk kawasan. ADB akan memperbesar dukungan bagi barang publik untuk kawasan dan tindakan kolektif guna memitigasi risiko lintas batas yang berkaitan dengan perubahan iklim, polusi lingkungan, ketahanan energi dan keamanan pasokan air, serta penyakit menular dan infeksi. Hal ini akan memerlukan kerja sama kawasan yang lebih besar di bidang-bidang seperti pembiayaan risiko bencana, pengembangan daerah aliran sungai, kebijakan kesehatan, standar sanitasi dan fitosanitasi, serta karantina.

66. Memperkuat kerja sama di sektor keuangan. ADB akan memperkuat kerja sama sektor keuangan dengan mengembangkan pasar obligasi kawasan, memfasilitasi kerangka kerja bersama dalam peraturan dan pengawasan keuangan, serta mendorong langkah-langkah harmonisasi transaksi keuangan lintas batas. ADB akan mendukung pendekatan bersama oleh DMC untuk mendorong stabilitas keuangan dan ekonomi kawasan. ADB akan membantu DMC berpartisipasi dalam forum global dan kawasan mengenai transparansi pajak dan kegiatan anti-pencucian uang, serta pembiayaan kontraterorisme.

67. Memperkuat prakarsa daerah. Sejak awal 1990an, ADB telah mengedepankan berbagai platform kerja sama daerah, seperti Program Subkawasan Sungai 
Mekong (Greater Mekong Subregion - GMS), Program Kerja Sama Ekonomi Kawasan Asia Tengah (Central Asia Regional Economic Cooperation - CAREC), dan Program Kerja Sama Ekonomi Subkawasan Asia Selatan (South Asia Subregional Economic Cooperation - SASEC). ADB juga telah ikut serta dalam Forum Kepulauan Pasifik (Pacific Islands Forum) dan Asosiasi Negara-Negara Asia Tenggara (ASEAN). Melalui prakarsa tersebut ADB akan memperluas dialog kebijakan ke bidang-bidang seperti rantai nilai pertanian, pendidikan, peningkatan keterampilan, pasar tenaga kerja, dan layanan kesehatan. ADB akan memfasilitasi berbagi pengetahuan dan kerja sama di antara subkawasan, dan akan bekerja sama dengan berbagai prakarsa internasional dan kawasan yang mulai digagas. 


\section{MEMPERLUAS OPERASI SEKTOR SWASTA}

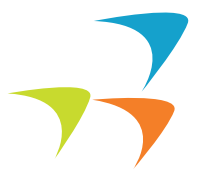

68. Meningkatkan operasi sektor swasta untuk mendukung tujuh prioritas operasional. ADB akan memperluas dan memperlebar operasi sektor swasta untuk mendukung tujuh prioritas operasional. Sektor swasta memobilisasi sumber daya untuk pembangunan; menciptakan pekerjaan; membantu mendorong inovasi dan efisiensi dalam DMC; dan membawa kelompok miskin, perempuan, dan kelompok rentan ke dalam perekonomian arus utama. Sektor swasta juga sangat penting dalam mengatasi kesenjangan pasar cukup besar yang ada di Asia dan Pasifik - mulai dari pembiayaan perdagangan jangka pendek ${ }^{34}$ hingga pembiayaan UKM jangka menengah. ${ }^{35}$ Sumber daya swasta juga akan diperlukan guna mengisi kebutuhan pembiayaan jangka panjang yang besar bagi infrastruktur di kawasan ini. ${ }^{36}$

69. Target operasi sektor swasta. Operasi sektor swasta ADB akan mencapai sepertiga dari jumlah operasi ADB sampai dengan 2024.

70. Mandat ganda ADB. Operasi sektor swasta ADB akan membantu mengisi kesenjangan pasar di kawasan ini dan berkontribusi terhadap sektor swasta yang lebih dinamis, yang menyampaikan hasil pembangunan solid. ADB akan mengejar dampak pembangunan sebagai tujuan penting operasi sektor swasta. ADB juga akan memastikan profitabilitas dan keberlanjutan komersial-dengan memperhatikan bahwa keberhasilan komersial berkaitan dengan hasil pembangunan.

\section{Sifat operasi sektor swasta ADB sebagai tamba-}

han. Pelaku usaha sektor swasta memilih untuk bekerja sama dengan lembaga keuangan pembangunan seperti ADB karena lembaga semacam ini dapat membantu meningkatkan standar lingkungan, sosial, dan tata kelola; memberi pembiayaan yang tidak tersedia di pasar dengan syarat yang wajar; meningkatkan rancangan proyek dan hasil pembangunan; serta memit- igasi risiko yang dipersepsikan. ${ }^{37}$ ADB akan berupaya untuk memanfaatkan lebih lanjut berbagai keunggulan tersebut. Di samping menyediakan pembiayaan sendiri, ADB akan mengundang lebih banyak dana dari pasar. Melalui operasi sektor swastanya, ADB akan berupaya mendorong keberlanjutan komersial melalui standar yang tinggi dalam tata kelola perusahaan, integritas, transparansi, serta perlindungan sosial dan lingkungan; dan mengatasi kegagalan pasar tanpa mendistorsi pasar tersebut.

72. Menyiapkan proyek-proyek sektor swasta yang layak dibiayai. ADB akan membantu penyiapan proyek yang layak dibiayai, yang mampu menarik pembiayaan sektor swasta dengan (i) melakukan inkubasi dan persiapan proyek; (ii) memasukkan lebih banyak ekuitas ke dalam perusahaan, proyek, dan lembaga keuangan; (iii) membantu menjadikan proyek layak melalui partisipasi $A D B$, bantuan teknis, pembiayaan campuran (dengan

\section{ADB akan mengejar dampak pembangunan sebagai tujuan penting operasi sektor swasta. ADB juga akan memastikan profitabilitas dan keberlanjutan komersial- dengan memperhatikan bahwa keberhasilan komersial berkaitan dengan hasil pembangunan.}

\footnotetext{
34 A. Di Caprio, K. Kim, dan S. Beck. 2017. Trade Finance Gaps, Growth, and Jobs Survey. ADB Briefs. No. 83. Manila: ADB.

35 P. Vandenberg, P. Chantapacdepong, dan N. Yoshino, ed. 2016. SMEs in Developing Asia: New Approaches to Overcoming Market Failures. Tokyo: Asian Development Bank Institute.

36 ADB. 2017. Meeting Asia's Infrastructure Needs. Manila.

37 International Finance Corporation. 2011. International Finance Institutions and Development through the Private Sector. Washington, DC.
} 
dana konsesional dan dana perwalian/trust fund), serta instrumen lainnya seperti fasilitas pembiayaan siaga untuk kesenjangan kelayakan (standby viability gap financing facility); (iv) uji coba pendekatan, model, dan teknologi baru; dan (v) menyempurnakan profil risiko proyek dengan menggunakan produk-produk peningkatan kredit dan manajemen risiko ADB.

73. Memperluas cakupan sektor infrastruktur dan mendiversifikasi ke sektor-sektor yang lain. $A D B$ akan terus mendorong partisipasi sektor swasta dalam infrastruktur melalui pembiayaan perusahaan dan pembiayaan proyek. Operasi sektor swasta akan memperluas dukungan bagi (i) energi terbarukan dan sektor infrastruktur lainnya seperti transportasi, terutama transportasi perkotaan; (ii) air, sanitasi, dan pembiayaan yang berkaitan dengan sampah guna mendukung kota layak huni; dan (iii) teknologi komunikasi baru yang ditargetkan ke daerah dan penduduk terpencil. ADB akan meningkatkan pembiayaannya bagi agribisnis. ADB juga akan mendukung sektor sosial, seperti kesehatan dan pendidikan, melalui perusahaan swasta dengan fokus pada model baru dan solusi yang terjangkau.

74. Memperluas cakupan geografis. ADB akan memperluas operasi sektor swasta ke tempat-tempat baru, termasuk pasar yang sulit seperti FCAS dan SIDS. Dalam prosesnya ADB akan mempertimbangkan ukuran transaksi yang lebih kecil dengan potensi risiko dan dampak pembangunan yang lebih tinggi, termasuk model bisnis inklusif.

75. Mendukung inklusi keuangan yang lebih besar. Operasi sektor swasta ADB akan mengembangkan sektor keuangan di DMC guna mencapai inklusi keuangan yang lebih besar; kesetaraan gender; penciptaan lapa- ngan kerja; dan akses ke perumahan yang terjangkau, asuransi, dan tabungan. Untuk mengatasi kesenjangan pembiayaan jangka pendek, ADB akan meningkatkan dukungannya bagi lembaga keuangan bank dan nonbank di DMC guna membantu meningkatkan kapasitas, kualitas, dan jangkauan lembaga-lembaga tersebutterutama ke penduduk berpenghasilan rendah. ADB akan memperluas penggunaan dan jangkauan berbagai program sektor keuangan, seperti pembiayaan perdagangan, pembiayaan rantai pasokan, dan pembiayaan mikro.

76. Memperkuat sektor keuangan dan pasar modal. Untuk mengatasi kesenjangan dalam pembiayaan jangka menengah hingga panjang, $A D B$-melalui operasi sektor swasta dan juga pinjaman berbasis kebijakan (PBL) kepada negara, bantuan teknis, peningkatan kapasitas, dan kegiatan pengetahuan-akan membantu mengembangkan pasar obligasi, terutama obligasi proyek, termasuk melalui peningkatan dan penjaminan kredit langsung. ADB akan melakukan kerja sama yang lebih besar dengan Prakarsa Pasar Obligasi Asia ASEAN+3 dan Jaminan Kredit, serta Fasilitas Investasi. ${ }^{38}$

77. Menggunakan dana ekuitas swasta untuk memperluas jangkauan. Dana ekuitas swasta adalah salah satu cara penting untuk menyampaikan bantuan ADB mengingat pengaruh manfaat dan mobilisasinya yang besar. ADB akan berfokus pada infrastruktur, sektor keuangan, dan perubahan iklim.

78. Meningkatkan dukungan bagi kerja sama pemerintah-badan usaha. ADB akan memperluas dukungannya untuk PPP dengan (i) membantu advokasi kebijakan dan peningkatan kapasitas; (ii) membantu

\section{Operasi sektor swasta ADB dapat membantu meningkatkan standar lingkungan, sosial, dan tata kelola; memberi pembiayaan yang tidak tersedia di pasar dengan syarat yang wajar; meningkatkan rancangan proyek dan hasil pembangunan; serta memitigasi risiko yang dipersepsikan.}

38 ASEAN+3 terdiri atas 10 negara anggota ASEAN ditambah Jepang, RRT, dan Republik Korea. 
menyiapkan lingkungan yang memungkinkan PPP; (iii) memberi layanan konsultasi transaksi; (iv) membantu pengembangan, penstrukturan, dan persiapan proyek; serta ( $v$ ) memberi pembiayaan proyek melalui pinjaman yang dijamin dan tidak dijamin pemerintah. Sebagai pengembang proyek, ADB akan meningkatkan layanan konsultasi transaksi guna membantu klien menstrukturkan PPP dan membangun daftar proyek yang baik.

79. Menggunakan pendekatan Satu ADB. Operasi sektor swasta ADB akan menarik pelajaran dari operasi sektor publik guna menyediakan solusi terintegrasi. Operasi sektor publik (baik pinjaman proyek maupun
PBL) dapat melengkapi operasi sektor swasta dengan menciptakan kondisi hulu agar sektor swasta dapat berkembang atau dengan menyiapkan BUMN untuk pembiayaan komersial. ADB akan menyatukan sumber daya sektor publik, sektor swasta, dan yang berfokus pada PPP guna menyampaikan paket solusi menyeluruh bagi DMC.

80. Kehadiran yang lebih besar di lapangan. Mengingat sebaran geografis operasi sektor swasta yang makin luas, ADB akan menempatkan lebih banyak staf operasi sektor swasta di kantor perwakilan dan meningkatkan pelatihan serta dukungan bagi direktur negara dan staf di lapangan. 

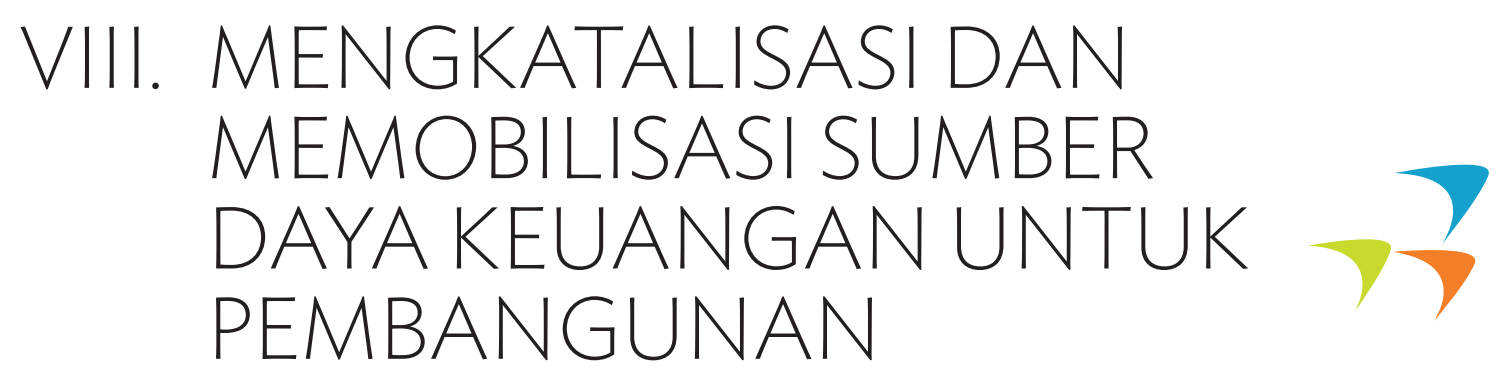

81. Membangun kemitraan kuat untuk mobilisasi sumber daya. Membangun kemitraan kuat dengan berbagai lembaga, seperti lembaga keuangan swasta dan pemerintah, serta mitra pembangunan tradisional dan baru, akan menjadi fokus utama Strategi 2030 guna memobilisasi lebih banyak sumber daya bagi operasi sektor publik dan swasta ADB. Ukuran penting keberhasilan ADB adalah volume dan kualitas sumber daya tambahan yang berhasil dimobilisasi di luar pembiayaan dari kami sendiri.

\section{Membangun kemitraan kuat dengan berbagai lembaga, seperti lembaga keuangan swasta dan pemerintah, serta mitra pembangunan tradisional dan baru, akan menjadi fokus utama Strategi 2030.}

82. Target pembiayaan bersama jangka panjang untuk operasi sektor swasta. ADB akan menargetkan kenaikan besar pembiayaan bersama (cofinancing) jangka panjang sampai dengan 2030, dengan setiap \$1 pembiayaan untuk operasi sektor swastanya diimbangi dengan $\$ 2,50$ pembiayaan bersama jangka panjang. ${ }^{39}$

83. Memobilisasi pembiayaan dari sumber komersial. ADB akan memperkuat upayanya memobilisasi pem- biayaan dari pihak swasta untuk pembiayaan bersama dan investasi, serta meningkatkan manfaat dari pembiayaan $A D B$ sendiri. ADB akan mencari peluang pembiayaan bersama, terutama dalam operasi infrastruktur dengan kebutuhan pembiayaan yang tinggi. ADB akan proaktif menggunakan produk peningkatan kredit, termasuk B loan, jaminan risiko sebagian, jaminan kredit sebagian, transfer risiko paparan ADB ke perusahaan asuransi, dan pengaturan berbagi risiko dalam pembiayaan perdagangan, hingga mengundang modal swasta. ADB juga akan menggunakan gabungan unik pengetahuan keuangan sektor swasta dan hubungan mendalam dengan sektor publik untuk menyampaikan solusi inovatif.

84. Penjaminan dan sindikasi. ADB akan menjamin dan selanjutnya melakukan sindikasi proyek besar, termasuk dalam mata uang setempat, guna memastikan ketersediaan pembiayaan bagi sponsor proyek.

\section{Memperluas kemitraan dengan investor kelem-} bagaan. Guna memaksimalkan peluang untuk memobilisasi dana swasta jangka panjang, ADB akan memperluas kemitraan dengan investor kelembagaan, seperti perusahaan asuransi dan pensiun di dalam dan di luar Asia. Berdasarkan keberhasilan Leading Asia's Private Sector Infrastructure Fund (saat ini dengan investasi ekuitas dari Jepang), ADB akan memperluas platform untuk mengelola dana pihak ketiga. Platform seperti ini akan melaksanakan pembiayaan bersama dengan operasi sektor swasta ADB, berdasarkan pemilihan dan manajemen transaksi ADB.

\section{Mengkatalisasi investasi melalui kerja sama pe-} merintah-badan usaha. Melalui upaya untuk mening-

39 Target ini didasarkan pada rasio pembiayaan bersama jangka panjang total untuk operasi sektor swasta terhadap total komitmen OCR untuk operasi sektor swasta selama 3 tahun terakhir. Pembiayaan bersama jangka panjang mencakup pinjaman paralel dan ekuitas yang dikaitkan dengan kegiatan pembiayaan atau konsultasi ADB, B loan, porsi pinjaman yang tidak tercakup dalam jaminan ADB, dana paralel, dan headroom reliefyang timbul dari pengaturan transfer risiko. Pembiayaan tersebut tidak mencakup Pembiayaan Perdagangan dan Pembiayaan Rantai Pasokan. Total komitmen OCR tidak termasuk headroom relief yang timbul dari pengaturan transfer risiko. 
katkan dukungan bagi PPP (paragraf 78), ADB akan membantu berbagai negara memobilisasi ragam sumber daya keuangan yang lebih luas. Bantuan ADB untuk mengembangkan, menstrukturkan, dan menyiapkan proyek PPP yang layak dibiayai akan membantu menciptakan lebih banyak peluang bagi investasi dan partisipasi sektor swasta. ADB akan meningkatkan penggunaan Asia Pacific Project Preparation Facility (saat ini didukung oleh Australia, Kanada, dan Jepang), serta fasilitas pengembangan proyek lainnya guna mendukung kegiatan persiapan proyek PPP.

\section{Memobilisasi pembiayaan dari sumber konse-} sional. Mobilisasi pembiayaan konsesional dari mitra bilateral dan multilateral, termasuk Green Climate Fund, Climate Investment Funds, dan Global Environment Facility, masih menjadi komponen utama dari upaya mobilisasi sumber daya ADB. Pembiayaan konsesional adalah alat yang sangat penting bagi DMC untuk membiayai proyek sambil memastikan keberlanjutan utang. Melanjutkan rekam jejak keberhasilan mengelola sumber daya pembiayaan konsesional campuran dari Clean Technology Fund dan Canadian Climate Fund for the Private Sector in Asia, ${ }^{40}$ ADB akan menggunakan sumber daya konsesional secara selektif untuk mengkatalisasi sumber daya swasta guna mendukung proyek yang berdampak pembangunan tinggi, jika ada potensi kuat bagi percontohan, replikasi, peningkatan skala, dan keberlanjutan komersial sesuai prinsip-prinsip yang disetujui. ${ }^{41}$

\section{Memperluas kerja sama dengan mitra baru dan} yang mulai muncul. ADB akan memperluas kemitraan dengan perusahaan dan yayasan filantropi. Solusi pendanaan yang inovatif akan dikaji untuk meningkatkan ketersediaan sumber daya bagi proyek. ADB akan memperkuat kerja sama dengan mitra multilateral yang baru, seperti Asian Infrastructure Investment Bank dan New Development Bank.
89. Menggalang lebih banyak sumber daya untuk dana perwalian ADB. ADB akan mencari lebih banyak sumber daya hibah untuk dana perwalian donor tunggal atau multidonor. ${ }^{42}$ ADB akan memastikan penggunaan sumber daya tersebut secara efektif dan efisien bagi proyek investasi dan bantuan teknis untuk peningkatan kapasitas yang didanai hibah, persiapan proyek, dan pekerjaan pengetahuan. Dalam interaksi yang erat dengan kontributor dana tersebut, ADB akan menggunakan sumber daya tersebut secara strategis untuk mengedepankan inovasi, meningkatkan kualitas proyek, dan memberi dukungan penting bagi pelaksanaan proyek.

90. Menggunakan instrumen inovatif untuk pendanaan ADB sendiri. Sebagai bagian dari upaya mobilisasinya, ADB akan-melalui operasi perbendaharaan-terus menggunakan instrumen inovatif seperti obligasi berwawasan lingkungan (green bond), obligasi untuk proyek terkait air (water bond), dan obligasi energi bersih. Lebih lanjut lagi, ADB akan mengkaji obligasi SDG dan pembiayaan syariah untuk memobilisasi dana bagi operasinya.

\section{ADB menargetkan kenaikan besar pembiayaan bersama (cofinancing) jangka panjang sampai dengan 2030, dengan setiap \$1 pembiayaan untuk operasi sektor swastanya diimbangi dengan \$2,50 pembiayaan bersama jangka panjang.}

40 Ini termasuk Canadian Climate Fund for the Private Sector in Asia dan Canadian Climate Fund for the Private Sector in Asia II.

41 Development Finance Institutions Working Group on Blended Concessional Finance for Private Sector Projects Summary Report October 2017 disusun oleh kelompok yang terdiri atas African Development Bank, Asian Development Bank, Asian Infrastructure Investment Bank, European Bank for Reconstruction and Development, European Development Finance Institutions, European Investment Bank, Inter-American Development Bank Group, Islamic Corporation for the Development of the Private Sector, dan International Finance Corporation.

42 Sampai dengan Maret 2017, ADB mengelola 49 dana perwalian, dengan 28 di antaranya berupa dana mitra-tunggal dan 21 dana multi-mitra. Sekitar $6 \%$ dari pembiayaan bersama resmi disalurkan melalui dana perwalian ADB. 
91. Meningkatkan lingkungan usaha untuk mengkatalisasi investasi swasta. ADB akan membantu DMC mengembangkan lingkungan kebijakan yang mendukung dan infrastruktur berkualitas agar dapat menarik investasi sektor swasta melalui saran kebijakan, bantuan teknis, PBL, dan pinjaman proyek. Analisis yang diperbarui mengenai kendala pasar penting yang diperoleh melalui operasi sektor swasta akan menjadi masukan bagi intervensi sektor publik di bidang-bidang ini.

92. Meningkatkan mobilisasi sumber daya domestik. Investasi publik yang dibiayai anggaran pemerintah adalah cara yang paling dominan untuk membiayai infrastruktur dan layanan publik. Guna memobilisasi lebih banyak sumber daya domestik, ADB akan terus mendukung pemerintah DMC dalam memperkuat sistem pengumpulan pendapatan dan manajemen pengeluaran. ADB juga akan membantu memperkuat transparansi dan manajemen utang DMC guna memastikan keberlanjutan utang dalam koordinasi dengan mitra pembangunan yang lain. Dukungan ADB untuk DMC dalam pengembangan lembaga keuangan dan pasar modal akan membantu menyalurkan tabungan di kawasan ini secara lebih efektif untuk investasi produktif. Perluasan operasi ADB dalam mata uang setempat akan membantu mengembangkan pasar mata uang setempat dan mengurangi risiko. 

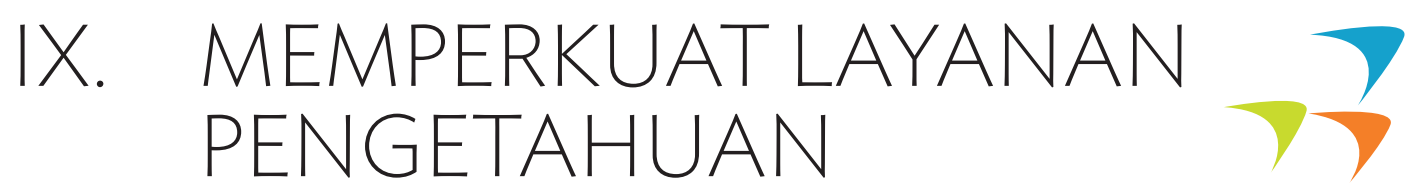

93. Peran ADB sebagai lembaga pengetahuan. Mengingat perubahan pesat di Asia dan Pasifik serta fakta bahwa kebanyakan DMC telah memperoleh status negara berpenghasilan menengah, relevansi ADB akan makin bergantung pada peran sebagai lembaga pengetahuan. Pengetahuan ADB yang bersifat tacit knowledge melekat dalam proyek dan programnya. Pengetahuan eksplisit ADB diberikan melalui berbagai produk dan layanan, seperti publikasi, forum, dan bantuan teknis. Meskipun DMC bisa mengambil sumber pembiayaan lain, klien sering beralih ke ADB karena standar tinggi dalam rancangan dan pelaksanaan proyek; transfer teknologi dan praktik-praktik baik; serta, secara umum, dibagikannya pengetahuan, keterampilan, dan keahlian yang terakumulasi selama lebih dari 50 tahun ADB bekerja sama dengan DMC.

94. Memperkuat peran ADB sebagai penyedia pengetahuan. ADB akan bekerja sama erat dengan DMC guna mengidentifikasi kebutuhan DMC dan menghasilkan produk dan layanan pengetahuan yang paling relevan. ADB juga bersiap menghasilkan, menyimpan, dan membagikan pengetahuan sebagai antisipasi kebutuhan DMC yang mulai muncul dan kebutuhan di masa mendatang. ADB akan memberi insentif bagi stafnya untuk mengintegrasikan pengetahuan terbaik yang tersedia dengan pembiayaan dan peningkatan kapasitas kelembagaan di sepanjang siklus operasional. ADB akan meningkatkan penyimpanan tacit knowledge, termasuk pembelajaran yang diperoleh di sepanjang siklus proyek, dan mengalokasikan bantuan teknis dan sumber daya lainnya secara strategis dan memadai guna mendukung layanan pengetahuan. ADB juga akan menggunakan bukti dan temuan dari evaluasi independen dan mandiri saat merancang program dan proyek baru. Penggunaan sumber daya bantuan teknis untuk mendukung penciptaan pengetahuaan akan ditinjau setiap tahun. Kelompok sektor dan tematik akan didorong untuk menjalankan dana perwalian guna memperkuat pekerjaan pengetahuannya.

95. Memastikan peran yang lebih proaktif untuk penelitian. Penelitian berbasis bukti dan pengetahuan ADB akan meningkatkan pemahaman dan kesadaran mengenai bidang dan sektor penting yang memerlukan tindakan, dan mendukung kebijakan serta reformasi yang baik oleh DMC. ADB akan makin memperkuat kapasitas penelitiannya dan memberi saran kebijakan berkualitas tinggi bagi DMC. Produk penelitian ADB juga akan berkontribusi terhadap diskusi pembangunan global dengan menawarkan perspektif dari Asia dan Pasifik.

96. Memperkuat kapasitas kelembagaan negara berkembang anggota ADB. ADB akan terus bekerja sama dengan pejabat pemerintah DMC untuk meningkatkan kemampuan DMC mengatasi masalah pembangunan dan menyampaikan proyek. ADB akan menghubungkan pejabat DMC, sektor swasta, masyarakat madani, dan akademisi dengan simpul pengetahuan kawasan dan global, serta pusat pembelajaran; dan memfasilitasi kerja sama antar-negara di dalam kawasan dan di luar kawasan. Selain itu, untuk mendukung peningkatan kapasitas dan dialog kebijakan di DMC, ADB akan menggunakan sumber daya bantuan teknis untuk mengujicobakan pendekatan dan solusi inovatif di

\section{Mengingat perubahan pesat di Asia dan Pasifik serta fakta bahwa kebanyakan DMC telah memperoleh status negara berpenghasilan menengah, relevansi ADB akan makin bergantung pada peran sebagai lembaga pengetahuan.}


bidang atau sektor tertentu dengan tujuan mereplikasi pendekatan yang berhasil pada skala lebih besar.

97. Mengedepankan pengetahuan di seluruh lembaga. Semua departemen akan didorong untuk menghasilkan produk dan layanan pengetahuan, serta berkontribusi bagi upaya peningkatan kapasitas di bidang keahlian masing-masing. Kelompok sektor dan tematik akan terus memimpin dan mengkoordinasikan kegiatan pengetahuan ADB. Fungsi penelitian ADB dan ADB Institute akan terus memberi landasan analisis bagi operasi dan saran kebijakan ADB. Pengetahuan internal di bidangbidang seperti evaluasi, manajemen hasil, antikorupsi dan integritas, hukum, pengadaan, audit dan kendali internal, manajemen risiko, operasi perbendaharaan, dan teknologi informasi juga akan mendukung DMC.

98. Memperluas kemitraan pengetahuan. ADB akan aktif mengembangkan dan membina kemitraan peng- etahuan dengan mitra bilateral dan multilateral, think tank, universitas, CSO, yayasan, dan sektor swasta. Kemitraan seperti ini akan menyediakan platform untuk menguji gagasan, mengumpulkan beragam pemikiran mengenai persoalan pembangunan penting, dan bersama-sama mengembangkan dan membagikan pengetahuan. Kemitraan ini akan mendukung pengumpulan data kawasan di bidang-bidang penting seperti SDG, perubahan iklim, urbanisasi, dan penelitian sebagai informasi untuk pekerjaan operasional.

99. Menyebarkan pengetahuan. ADB akan terus meningkatkan aksesibilitas pengetahuan yang diperoleh dari kegiatan operasional, penelitian, dialog kebijakan, dan upaya peningkatan kapasitas. ADB juga akan meningkatkan fungsi komunikasinya. ADB akan menggunakan berbagai kanal komunikasi dan teknologi digital untuk menyebarkan pengetahuan secara eksternal dan internal.

\section{ADB akan bekerja sama erat dengan DMC guna mengidentifikasi kebutuhan DMC dan menghasilkan produk dan layanan pengetahuan yang paling relevan.}




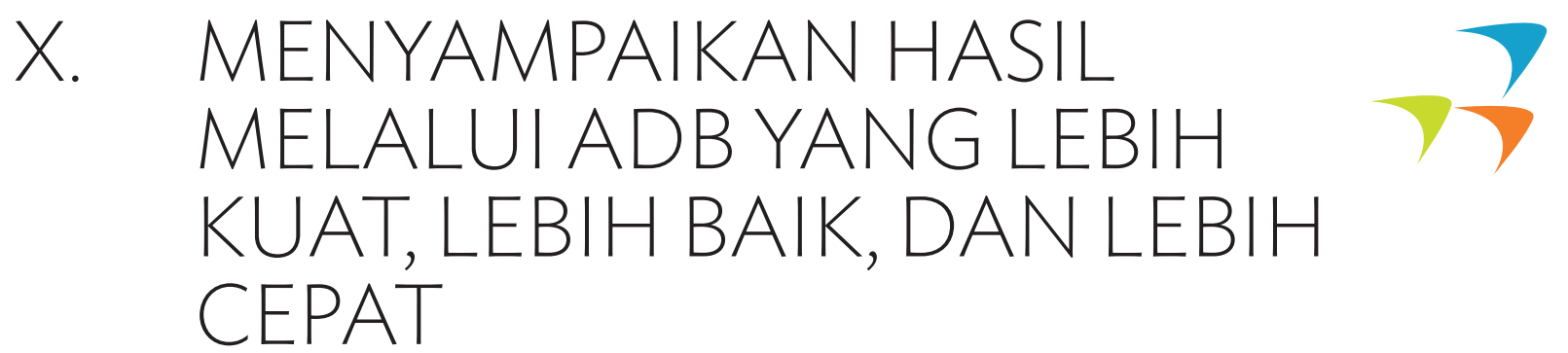

100. Memastikan basis sumber daya yang kuat. Setelah penggabungan operasi peminjaman ADF dengan neraca keuangan sumber daya modal biasa (OCR), ADB memiliki basis modal yang solid untuk mendukung operasi yang digambarkan dalam Strategi 2030. Untuk mempertahankan posisi modal yang baik, ADB akan terus merampingkan biaya administratif dan operasional internal, serta menggali berbagai opsi untuk menghasilkan pertumbuhan modal secara organik. Untuk mengoptimalkan penggunaan modalnya dan mendorong keberlanjutan keuangan, ADB akan meninjau kerangka kerja kecukupan modal dan penetapan harga secara berkala; menggunakan pengaturan transfer risiko seperti reasuransi, jaminan, dan penjualan untuk mengurangi paparan ADB; serta memaksimalkan penggunaan dana komersial dan konsesional pihak ketiga dan peluang pembiayaan bersama. Peningkatan modal secara umum atau secara khusus mungkin dapat dipertimbangkan pada saat yang tepat berdasarkan kebutuhan pembiayaan dan tergantung dukungan dari pemegang saham.

101. Meningkatkan sumber daya manusia. ADB akan memperluas jumlah tenaga ahlinya, mempekerjakan ahli di bidang prioritas yang baru, dan merampingkan proses perekrutan dengan tiga tujuan, yaitu kecepatan, kualitas, dan transparansi. ADB akan berinvestasi dalam pelatihan dan pengembangan stafnya (termasuk operasi, kepemimpinan, teknologi digital, dan manajemen perubahan). Program pelatihan akan mendukung pemahaman dan kerja sama di antara staf yang menangani operasi sektor publik dan swasta. Sistem manajemen kinerja ADB akan lebih diperkuat untuk memotivasi staf dan memungkinkan budaya yang berkinerja tinggi. Mobilitas staf, termasuk penugasan dan rotasi jangka pendek, ke berbagai departemen, dan di antara kantor perwakilan dan markas besar, akan ditingkatkan guna memperluas keterampilan staf, memfasilitasi berbagi pengetahuan, dan mendorong inovasi. Selain itu, ADB berkomitmen atas keragaman angkatan kerjanya, termasuk dengan mendorong keimbangan gender dan lingkungan kerja yang menghormati semua pihak.

102. Mempertahankan kehadiran kuat di negara. Kantor perwakilan akan makin diperkuat agar berfungsi sebagai pelayanan satu atap bagi negara mitra bersangkutan untuk semua produk dan layanan ADB. ADB akan memperkuat kapasitas teknis kantor perwakilan dengan memastikan bahwa kantor tersebut memiliki campuran keterampilan yang tepat di berbagai sektor, tematik, operasi pemerintah, dan operasi swasta berdasarkan kebutuhan negara tersebut. Kehadiran ADB di lapangan bagi negara-negara FCAS dan SIDS akan makin diperkuat. Kantor perwakilan akan bekerja sama erat dengan kelompok sektor dan tematik guna memperdalam kualitas dialog dengan mitra negara, sehingga memungkinkan tanggapan yang tepat waktu untuk saran mengenai persoalan kebijakan, dan memfasilitasi dukungan pelaksanaan proyek yang efektif.

\section{Menyempurnakan produk dan instrumen ADB.} ADB akan makin menajamkan dan memperluas produk dan instrumen guna memberi dukungan yang disesuaikan bagi klien sektor publik dan swasta. Dalam operasi pemerintah, ADB akan terus menawarkan menu berbagai instrumen pinjaman agar DMC memiliki fleksibilitas untuk menentukan cara mencapai hasil pembangunan. Meskipun pinjaman proyek secara tradisional adalah cara pembiayaan yang paling umum dan efektif untuk berbagi pengetahuan dan keahlian dalam merancang dan melaksanakan proyek, penggunaan PBL dan pinjaman berbasis hasil terus meningkat di sejumlah DMC. Mengingat kebutuhan klien yang makin beragam dan rumit, ADB akan menggunakan kedua instrumen tersebut secara efektif. Pada operasi sektor swasta, ADB akan terus menajamkan dan memperlu- 
as produk dan cara penyediaannya, termasuk melalui investasi ekuitas dan produk peningkatan kredit. ADB akan menyediakan solusi pembiayaan mata uang setempat bagi operasi sektor publik dan swasta.

104. Memodernisasi proses bisnis dan meningkatkan efisiensi operasional. ADB akan melaksanakan modernisasi dramatis terhadap proses bisnisnya dengan memanfaatkan teknologi yang tersedia. ADB akan makin meningkatkan efisiensi operasionalnya dan mengurangi waktu yang diperlukan untuk menyiapkan dan mengurus pinjaman, hibah, dan bantuan teknis tanpa mengkompromikan kualitas dan integritas. ADB akan merampingkan proses bisnis untuk layanan konsultasi, uji coba, dan pembelian peralatan dan layanan bagi operasi dan pemeliharaan. ADB akan melaksanakan program ketangguhan organisasi yang kuat demi memperkuat kontinuitas bisnis dan kemampuan menanggapi krisis.

105. Mendorong transformasi digital. Untuk melengkapi moderminasi proses bisnis, ADB akan memanfaatkan secara optimal berbagai sistem dan proses digital teknologi informasi yang aman dan modern guna meningkatkan efektivitas, efisiensi, dan ketangguhan. Transformasi digital ADB akan memfasilitasi akses secara real-time ke data mengenai semua aspek operasi dan administrasinya. ADB akan menciptakan platform digital yang memfasilitasi pembuatan rangkaian luas produk dan layanan pengetahuan, serta menjadikan produk dan layanan tersebut mudah diakses mitra dan pemangku kepentingan. ADB juga akan mendukung produk keuangan yang inovatif dan memfasilitasi budaya inovasi dan kecepatan tanggap terhadap kebutuhan klien yang berubah.

106. Mencapai pengadaan yang tepat waktu dan hemat biaya. ADB akan terus mendorong sistem pengadaan yang lebih baik dengan menggunakan pendekatan berbasis prinsip dan risiko. ${ }^{43}$ ADB akan terus mendukung DMC untuk memperkuat kapasitas pengadaan. ADB juga akan mendukung pengadaan teknologi tingkat tinggi dan lebih banyak menggunakan sistem pengadaan dari pihak-pihak yang menyediakan pembiayaan bersama. Bentuk pengadaan yang cocok untuk tujuan (fit-for-purpose) akan mendukung proyek inovatif dengan menggunakan teknologi maju dan rangkaian luas produk dan layanan pengetahuan ADB.

\section{Meningkatkan penggunaan sistem negara. ADB} akan berupaya meningkatkan penggunaan sistem negara dalam operasi sektor publiknya guna membantu mengurangi keterlambatan pelaksanaan proyek, memotong biaya transaksi, meningkatkan rasa memiliki negara, serta memperkuat lembaga dan sistem DMC. ADB akan mendukung penggunaan sistem negara dalam pengadaan, manajemen keuangan publik, serta perlindungan lingkungan dan sosial. Karena kekuatan sistem negara bervariasi di antara DMC, akan digunakan pendekatan yang disesuaikan bagi konteks tertentu guna memastikan agar standar ADB diikuti.

108. Memperkuat kerja sama dengan organisasi masyarakat madani. ADB akan bekerja sama dengan CSO untuk memanfaatkan kekuatan uniknya, seperti keberadaan setempat dan pengetahuan khusus. ADB akan menggali peluang untuk meningkatkan keterlibatan CSO dalam perancangan dan pelaksanaan proyek yang didukung ADB. Fokus akan diberikan terutama bagi operasi yang menggunakan pendekatan partisipatif akar rumput untuk menargetkan kelompok miskin dan rentan, memobilisasi perempuan dan kelompok muda, serta memantau kegiatan dan keluaran proyek. ADB juga akan meminta masukan dan saran CSO mengenai tinjauan kebijakan utama ADB.

109. Operasionalisasi strategi. Jajaran manajemen akan segera melaksanakan Strategi 2030 setelah disetujui oleh Dewan Direktur. ${ }^{44}$ Mengingat panjangnya jangka waktu strategi ini dan kebutuhan pembangunan DMC yang berevolusi dengan cepat, ADB harus fleksibel dan responsif selama pelaksanaan strategi yang baru. ADB akan merencanakan, melaksanakan, dan memantau kinerja secara sistematis melalui berbagai kanal. Pertama, fokus strategis, bidang pelibatan spesifik, pendekatan, dan persyaratan keterampilan secara umum bagi setiap prioritas operasional akan dijelaskan dalam rencana operasional yang terpisah. Kedua, CPS akan menajamkan lebih lanjut prioritas dan selektivitas operasi $A D B$ berdasarkan keadaan, tantangan,

\footnotetext{
43 ADB. 2017. Improving ADB Project Performance through Procurement Reforms. Manila.

44 Strategi 2030 akan menggantikan Strategi 2020 dan Kajian Tengah Waktu Strategi 2020.
} 
dan kebutuhan unik masing-masing DMC; serta potensi memberi nilai tambah dalam batas kapasitas dan sumber daya ADB. Ketiga, program kerja dan proses kerangka kerja anggaran akan diperkuat dan digunakan untuk menyelaraskan rencana kerja tahunan, serta pengaturan sumber daya dengan prioritas operasional.

110. Memantau hasil. Kerangka kerja hasil korporasi akan dikembangkan untuk memantau dan mengukur kemajuan pelaksanaan. Kerangka kerja tersebut akan mencakup indikator hasil dan target untuk prioritas Strategi 2030. Kerangka kerja hasil pertama yang diselaraskan dengan Strategi 2030 akan mencakup periode 6 tahun dari 2019 sampai 2024. ADB akan memperbarui kerangka kerja hasil korporasinya pada akhir periode 6 tahun dan akan terus melaporkan kinerja kelembagaan secara tahunan menggunakan kerangka kerja hasil tersebut melalui DefR. 


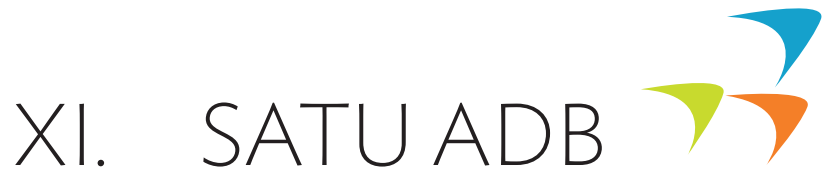

111. Menjalankan pendekatan Satu ADB. Untuk menyampaikan arahan yang ditetapkan dalam Strategi 2030, ADB akan memperkokoh pendekatan Satu $A D B$, dengan menyatukan keahlian dan pengetahuan pada berbagai rentang bidang yang ada di dalam ADB. Staf yang menangani operasi sektor publik dan swasta akan bekerja sama erat dalam merencanakan operasi, bersama-sama mengidentifikasi dan mengatasi ham- batan (bottleneck) hasil pembangunan, serta memroses proyek. ADB akan mengembangkan solusi terintegrasi yang memasukkan teknologi maju, dengan dukungan dari kelompok sektor dan tematik. Fungsi penelitian akan membantu meningkatkan landasan analisis bagi operasi dan dialog kebijakan dengan klien. Pendekatan Satu ADB akan didukung dengan mobilitas dan penghargaan staf melalui manajemen kinerja.

\section{Untuk menyampaikan arahan yang ditetapkan dalam Strategi 2030, ADB akan memperkokoh pendekatan Satu ADB, dengan menyatukan keahlian dan pengetahuan pada berbagai rentang bidang yang ada di dalam ADB.}




\section{LAMPIRAN: \\ MENGKAJI KEMBALI OPERASI ADB DAN RANGKUMAN KONSULTASI}

1. Asian Development Bank (ADB) telah memantau kemajuan pelaksanaan Strategi 2020.' Pada 2014, ADB mengadakan kajian tengah waktu Strategi 2020 dan mengembangkan rencana aksi untuk mengatasi berbagai tantangan yang teridentifikasi. ${ }^{2}$ Setiap tahun, tinjauan efektivitas pembangunan mengkaji kembali kinerja ADB dan membandingkannya dengan kerangka kerja hasil korporasi. Departemen Evaluasi Independen (IED) mengevaluasi kinerja ADB pada berbagai tingka$\tan$ (proyek, sektor, tema, program negara, dan kebijakan korporasi). Dalam mempersiapkan Strategi 2030, ADB juga mengumpulkan pandangan dari berbagai pemangku kepentingan di negara anggota, baik yang ada di kawasan maupun dari luar kawasan, sekaligus dari anggota dan staf Dewan ADB.

\section{A. Kajian Tengah Waktu Strategi 2020}

2. Kajian tengah waktu menganalisis pembelajaran dari pelaksanaan Strategi 2020 dan menilai tantangan yang ada saat ini maupun yang mulai timbul terhadap pembangunan di negara berkembang anggota $A D B$ (DMC). Kajian tengah waktu mendapati bahwa $A D B$ telah menyelaraskan operasinya dengan ketiga agenda strategis dari Strategi 2020, yaitu pertumbuhan ekonomi yang inklusif, pertumbuhan yang ramah lingkungan, dan integrasi regional. Selama 2008-2012, lebih dari $80 \%$ operasi ADB masuk dalam lima bidang inti Strategi 2020, dengan konsentrasi tinggi di sektor infrastruktur. Kajian tengah waktu juga mendapati bahwa efektivitas kelembagaan ADB masih perlu diperkuat, termasuk keterampilan staf dan proses bisnis. Kajian tengah waktu berkesimpulan bahwa Strategi 2020 masih valid dan relevan dalam arah strategisnya secara luas. Namun, kawasan ini berubah dengan cepat-dan ADB pun harus mengikuti perubahan itu dengan cepat. Berdasarkan analisis dan penilaian tersebut, kajian tengah waktu menggarisbawahi program 10 butir guna menajamkan arah strategis ADB di masa mendatang hingga 2020 dan memperkuat kecepatan tanggap ADB.

i. Pengurangan kemiskinan dan pertumbuhan ekonomi yang inklusif. $A D B$ perlu melanjutkan visinya berupa kawasan yang bebas dari kemiskinan-memberantas kemiskinan ekstrem serta mengurangi kerentanan dan ketimpangandengan memperluas dukungannya guna mencapai pertumbuhan ekonomi yang cepat dan inklusif. ADB akan meningkatkan dukungannya bagi kesehatan dan pendidikan, serta memberi lebih banyak sumber daya untuk DMC berpenghasilan rendah dan DMC dalam kondisi rapuh dan terdampak konflik.

ii. Lingkungan dan perubahan iklim. Mengingat kawasan Asia dan Pasifik menghadapi tantangan lingkungan yang serius, ADB akan meningkatkan dukungannya bagi adaptasi perubahan iklim, sambil mempertahankan bantuannya untuk mitigasi melalui energi bersih dan proyek efisiensi energi, serta transportasi yang ramah lingkungan.

iii. Kerja sama dan integrasi kawasan. $A D B$ akan memperluas konektivitas regional dan memperpanjang rantai nilai dengan mendukung investasi infrastruktur lintas batas dan menghubungkan simpul ekonomi untuk meningkatkan peluang perdagangan dan komersial.

iv. Pembangunan infrastruktur. Infrastruktur masih akan menjadi fokus penting operasi ADB. ADB akan berupaya memperkuat hasil proyek infrastruktur dengan meningkatkan pelibatan sektor, rancangan 
teknis, dan pelaksanaannya. ADB akan mendorong keberlanjutan infrastruktur dengan menekankan pada operasi dan pemeliharaan.

v. Negara berpenghasilan menengah. Mayoritas DMC akan mencapai status negara berpenghasilan menengah pada 2020, sehingga ADB perlu mempertajam pendekatan strategisnya agar tetap relevan dan responsif terhadap kebutuhan pembangunan DMC.

vi. Pengembangan dan operasi sektor swasta. $A D B$ akan memperluas bantuan bagi pembangunan dan operasi sektor swasta secara sistematis hingga $50 \%$ dari operasi tahunan sampai dengan 2020, termasuk meningkatkan operasi sektor swasta hingga 25\% dari operasi sumber daya modal biasa setiap tahunnya. ADB akan memperkuat lingkungan usaha di DMC untuk mendorong investasi swasta. Selain membiayai proyek, ADB juga akan menjadi pengembang proyek yang lebih aktif.

vii. Solusi pengetahuan. Pendekatan Satu ADB akan diadopsi agar semua departemen ADB dapat bekerja sama memberi solusi pengetahuan. Kantor perwakilan ADB di negara klien (resident mission) akan mencari kemitraan pengetahuan dan peluang dialog dengan DMC dan mengkoordinasikan dukungan ADB. Guna memastikan bahwa pekerjaan pengetahuan $A D B$ akan relevan secara operasional, komunitas praktisi ADB akan lebih terlibat aktif dalam pemrosesan proyek dan produk pengetahuan terkait. ${ }^{3}$

viii. Sumber daya dan kemitraan keuangan. Kawasan Asia dan Pasifik masih tetap memerlukan pembiayaan pembangunan skala besar. ADB tidak dapat mempertahankan relevansinya tanpa skala operasi tertentu yang didukung oleh sumber daya keuangan yang memadai. ADB akan meningkatkan kapasitas peminjamannya, termasuk melalui penggabungan operasi peminjaman Asian Development Fund dengan neraca keuangan sumber daya modal biasa. ix. Memberi nilai terbaik atas uang yang dikeluarkan. ADB akan berupaya meningkatkan efisiensi dan efektivitas. Guna mendukung pelaksanaan proyek yang lebih baik, $A D B$ akan mereformasi dan merampingkan proses bisnis, terutama sistem pengadaan ADB. ADB akan menerapkan kerangka kerja hasil secara lebih sistematis di tingkat korporasi, negara, dan proyek guna mengukur dan memantau kinerja.

x. Bersiap untuk menjawab tantangan baru. $A D B$ akan memperkuat keahlian stafnya, insentif, dan pengaturan kelembagaan secara menyeluruh agar dapat menjadi lembaga yang lebih dinamis, lincah, dan inovatif. Kantor perwakilan ADB di negara klien (resident mission) akan diberdayakan melalui pemberian wewenang dan mandat yang lebih besar.

\section{B. Tinjauan Efektivitas Pembangunan}

3. Tinjauan efektivitas pembangunan akhir-akhir ini menunjukkan bahwa ADB telah mengambil sejumlah langkah penting untuk menjadi lebih kuat, lebih baik, dan lebih cepat. Dalam hal menjadi lebih kuat dan memastikan keselarasan strategis, ADB akan mampu mencapai visi 2020 yang dijabarkan dalam Strategi 2020 dan kajian tengah waktu. Operasi yang mendukung kelestarian lingkungan terus bertambah, bersamaan dengan dukungan bagi mitigasi dan adaptasi perubahan iklim, pembangunan sektor swasta, dan peningkatan tata kelola dan kapasitas. ADB akan mampu memenuhi target kerja sama dan integrasi kawasan $(\mathrm{RCl})$ dan pengarusutamaan kesetaraan gender, tetapi meleset untuk target pembiayaan bersama karena kenaikan signifikan jumlah komitmen ADB. ${ }^{4}$ Kinerja di bidang pendidikan, kesehatan, dan perlindungan sosial masih beragam. Pengaruh dari diperkenalkannya target sektor kesehatan dan pendidikan setelah kajian tengah waktu menyebabkan naiknya penekanan pada kedua sektor tersebut. ${ }^{5}$ Namun, data menunjukkan bahwa pembiayaan operasi sektor kesehatan perlu lebih ditekankan lagi guna memenuhi target 2020.

Komunitas praktisi ini telah berevolusi menjadi kelompok sektor dan tematik.

4 ADB berkomitmen meningkatkan dukungan untuk RCI hingga mencapai setidaknya 30\% dari operasi keseluruhan pada 2020. Jumlah komitmen operasi sektor publik yang mendukung pengarusutamaan gender sebagai persentase dari komitmen total jumlah operasi sektor publik seharusnya akan mencapai 50\%. Keseluruhan pembiayaan bersama langsung setiap tahun seharusnya akan melebihi nilai pembiayaan proyek dari ADB sendiri. Pembiayaan sektor pendidikan dan kesehatan masing-masing akan mencapai 6\%-10\% dan 3\%-5\% dari pembiayaan ADB total. 
4. Dari segi peningkatan kualitas, kualitas sebagian besar proyek yang masuk telah membaik. Untuk proyek yang diselesaikan, kinerjanya terutama kuat pada penyampaian hasil kesetaraan gender dan proyek bantuan teknis. Secara keseluruhan, tren keberhasilan saat menyelesaikan operasi sektor publik terus naik, termasuk untuk pinjaman berbasis kebijakan, tetapi operasi sektor swasta lebih kesulitan dalam memperbesar tingkat keberlanjutan dan keberhasilan. ADB masih menghadapi tantangan untuk menjadi lebih cepat. Meskipun jarak waktu antara persetujuan dengan pemberian kontrak pertama sudah berkurang, sejumlah metrik penting seperti keterlambatan proyek, waktu pemrosesan internal, dan pemrosesan pengadaan menunjukkan masih diperlukannya pekerjaan lebih lanjut.

\section{Tinjauan Departemen Evaluasi Independen}

5. IED telah melakukan penilaian Strategi 2020 atas tiga agenda strategis (pertumbuhan ekonomi inklusif, pertumbuhan yang menjaga kelestarian lingkungan, dan $\mathrm{RCI}$ ) dan lima pendorong perubahan (pembangunan sektor swasta dan operasi sektor swasta, tata kelola yang baik dan peningkatan kapasitas, kesetaraan gender, solusi pengetahuan, dan kemitraan).

6. Dalam hal agenda strategis, IED menemukan bahwa bidang-bidang yang penting bagi pertumbuhan ekonomi inklusif, tetapi tidak diidentifikasi sebagai bidang operasional inti di bawah Strategi 2020-seperti kesehatan, pertanian, dan perlindungan sosialtelah diabaikan. IED mempertanyakan alasan mengapa bidang operasional didefinisikan sebagai inti dan non-inti, dan menyarankan agar praktik ini dihentikan. Walaupun diperlukan selektivitas dalam operasi, ADB seharusnya beradaptasi terhadap keadaan negara atau geografis, dan tidak seharusnya didorong oleh target sektor yang sifatnya dari atas ke bawah (top-down). Peningkatan dukungan bagi sektor sosial, dan juga bagi pertanian, kesetaraan gender, dan ketahanan pangan, akan memperkuat kontribusi keseluruhan ADB terhadap pertumbuhan ekonomi yang inklusif. Dalam hal pertumbuhan yang menjaga kelestarian lingkungan, meskipun proporsi proyek ADB yang ditandai mendukung pertumbuhan yang menjaga kelestarian lingkungan telah meningkat selama 2013-2015, hampir sepertiga dari proyek-proyek ini didapati hanya memili- ki manfaat lingkungan yang marginal atau tidak berarti. Dukungan ADB bagi perubahan iklim dan pertumbuhan yang menjaga kelestarian lingkungan seharusnya ditingkatkan lagi. Dalam hal RCI, IED menilai dukungan ADB layak dipuji. ADB berfokus terutama pada konektivitas fisik melalui infrastruktur lintas batas, dan ADB seharusnya lebih berupaya mendukung barang publik untuk kawasan, mendorong produktivitas lebih tinggi, meningkatkan daya saing perekonomian yang berpartisipasi, memitigasi kerentanan kawasan, dan mengatasi ketimpangan subkawasan.

7. Dalam hal pendorong perubahan, IED menemukan bahwa koordinasi internal ADB dan mekanisme dukungan bagi pembangunan sektor swasta masih lemah. Diperlukan lebih banyak upaya untuk bertindak sebagai Satu ADB. Kaitan antara kegiatan bidang publik dan swasta dalam strategi sektor, strategi kemitraan negara, dan kerangka kerja hasil yang berkaitan perlu diperkuat. ADB seharusnya berfokus pada mengurangi tingkat pembatalan, memperkuat volume dan kualitas investasi ekuitas, dan memperbanyak sindikasi dan jaminan. Dukungan lebih lanjut bagi proyek-proyek industri, perdagangan, manufaktur, dan agribisnis akan meningkatkan nilai tambah dari ADB. Dalam hal tata kelola, IED menyoroti bagaimana tata kelola yang baik memiliki potensi pengaruh transformasional atas hasil pembangunan dan menyarankan agar ADB melanjutkan dukungan di bidang ini meskipun tingkat keberhasilan penyelesaian proyek relatif rendah.

8. Dukungan bagi kesetaraan gender telah meningkat signifikan dengan Strategi 2020. Untuk melanjutkan pencapaian ini, ADB perlu menyempurnakan sistem pengkategorian gender dan pengumpulan data dasar yang dipilah menurut jenis kelamin. IED juga menyoroti perlunya mendokumentasikan hasil kesetaraan gender secara lebih sistematis di tingkat negara dan proyek. Dalam hal pengetahuan dan kemitraan, ADB seharusnya mengambil pendekatan yang lebih tematik dan terintegrasi terhadap operasi, berdasarkan model bisnis yang prinsip pusatnya adalah memanfaatkan pengetahuan dan pembiayaan. IED juga menganjurkan peningkatan keahlian dan kerja sama yang lebih kuat di seluruh departemen regional dan di antara pekerjaan sektor swasta dan publik. Pengalaman ADB dengan kemitraan pengetahuan untuk pekerjaan sektor dan tematik masih beragam. Proyek yang dibiayai bersama jauh 
lebih berhasil daripada proyek yang tidak memperoleh pembiayaan bersama. IED menyarankan perubahan pada tanggung jawab, sistem, dan aturan organisasi untuk memfasilitasi manajemen kemitraan yang lebih baik.

9. Untuk Strategi 2030, IED merekomendasikan agar ADB mengadopsi pencarian pertumbuhan yang berkualitas lebih baik (bukan sekadar taraf pertumbuhan), termasuk melalui tiga agenda yang saling memperkuat, yaitu inklusi sosial dan geografis, kelestarian lingkungan, serta kerja sama dan integrasi kawasan ( $\mathrm{RCl}$ ). Meskipun kebanyakan DMC sudah menjadi atau akan menjadi negara berpenghasilan menengah, negara-negara tersebut memiliki perbedaan dalam tingkat pendapatan, komposisi produk domestik bruto, profil kemiskinan, ketahanan pangan, dan kapasitas kelembagaan. Beberapa faktor yang memfasilitasi pertumbuhan dan pengurangan kemiskinan luar biasa selama hampir 2 dekade di Asia dan Pasifik, kini mulai surut. Lebih lanjut lagi, tren besar berupa perubahan iklim, tekanan terhadap lingkungan, penuaan, dan kemajuan teknologi yang pesat akan membawa lebih banyak tantangan. Karena itu, ADB perlu memberi solusi yang disesuaikan dengan memanfaatkan pembiayaan dan pengetahuan, dan dengan mengadopsi pendekatan yang lebih tematik dan terintegrasi terhadap operasi. ${ }^{6}$

\section{Konsultasi dengan Pemangku Kepentingan}

10. Sejak Oktober 2015, ADB telah melaksanakan banyak konsultasi di dalam dan di luar kawasan, dan juga secara internal, guna mencari pandangan dan perspektif berbagai pemangku kepentingan mengenai Strategi 2030. Perwakilan dari beragam bidang telah berpartisipasi, termasuk pemerintah pusat dan pemerintah daerah, organisasi masyarakat madani, think tank, lembaga akademis, dan sektor swasta.

11. Konsultasi dengan negara berkembang anggota ADB. Para pemangku kepentingan di DMC menyarankan agar pernyataan visi ADB diperluas untuk memasukkan rujukan terhadap pertumbuhan inklusif, pembangunan berkelanjutan, dan ketangguhan terh- adap ancaman ekonomi dan lingkungan. Banyak yang memandang infrastruktur dan $\mathrm{RCl}$ sebagai bidang kekuatan penting dan menyebutkan perlunya memperkuat kapasitas di sektor sosial. Dukungan bagi kerja sama pemerintah-badan usaha juga harus ditingkatkan. Pinjaman ADB perlu ditingkatkan lagi mengingat DMC menghadapi banyak tantangan pembangunan dan kendala pembiayaan, termasuk di negara berpenghasilan menengah. Pemangku kepentingan DMC menyoroti perlunya ADB mempertahankan fokus pada negara dan mengadopsi pendekatan yang fleksibel dan terintegrasi. Para pemangku kepentingan ini meminta bantuan ADB agar dapat memenuhi kontribusi yang ditentukan bagi setiap negara dan mendukung manajemen risiko iklim dan bencana, termasuk melalui mekanisme keuangan inovatif. Pemangku kepentingan tersebut mendesak ADB untuk merampingkan proses bisnis guna memotong biaya transaksi dan meningkatkan efisiensi, serta menekankan perlunya memfasilitasi berbagi pengalaman dan pengetahuan pembangunan di antara berbagai negara.

12. Konsultasi dengan negara maju. Para pemangku kepentingan di negara maju menyadari bahwa ADB perlu menjawab tantangan pembangunan yang baru di kawasan ini dan beradaptasi terhadap kebutuhan klien yang beragam. Para pemangku kepentingan mengakui kemampuan ADB untuk mengkatalisasi pembiayaan, mendorong dialog kebijakan, dan menyediakan solusi pengetahuan. Pemangku kepentingan tersebut merekomendasikan agar ADB meningkatkan operasi, termasuk pekerjaan sektor swasta dan kerja sama pemerintah-badan usaha, serta melakukan desentralisasi dengan menugaskan lebih banyak staf ke kantor lapangan. Pemangku kepentingan juga menyarankan agar ADB terus melindungi kelompok rentan, termasuk anak-anak, difabel, dan kelompok miskin perkotaan, serta menekankan bahwa ADB perlu berperan lebih aktif dalam memfasilitasi aliran pengetahuan di antara negara anggota yang perkembangannya masih rendah dengan perekonomian yang lebih maju di kawasan ini. Keterlibatan ADB di negara berpenghasilan menengah-atas (UMIC) perlu bersifat selektif, dengan fokus pada bidang-bidang yang dapat diberi nilai tambah terbesar.

6 ADB. 2017. Knowledge, Finance, and the Quality of Growth: An Evaluative Perspective on Strategy 2030. Manila. 
13. Kelompok lainnya. Donor Asian Development Fund menekankan bahwa ADB perlu mempertahankan fokus intinya pada pengurangan kemiskinan dan pertumbuhan inklusif. Para donor ini ingin melihat dukungan yang lebih besar bagi pembangunan sektor swasta, manajemen sektor publik, dan kerja sama regional. Donor juga mendukung diferensiasi klien yang lebih besar dalam strategi termasuk penjabaran strategi yang jelas untuk UMIC. Pemangku kepentingan di negara anggota yang sudah mencapai kelulusan mengakui peran ADB dalam mengkatalisasi dan memobilisasi pembiayaan swasta bagi pembangunan dan mencatat kemampuan ADB untuk memfasilitasi kerja sama kawasan, serta transfer pengetahuan dan teknologi. Para pemangku kepentingan juga menekankan pentingnya peran katalis ADB dalam mengatasi besarnya kesenjangan infrastruktur di kawasan ini. Staf ADB menyoroti perlunya berfokus ke bagian "bagaimana" dari Strategi 2030 guna menjawab bagian "apa” secara efektif. Para staf menyampaikan dukungan bagi kerja sama lintas sektor karena negara-negara klien menghadapi mas- alah lebih rumit yang memerlukan intervensi lintas sektor. Para staf juga menyadari perlunya ADB memberi keterampilan tambahan dan memberdayakan stafnya, mengingat penekanan yang makin kuat pada persoalan lintas sektor dan tematik.

\section{Pertemuan meja bundar bersama para pemikir} pembangunan terkemuka. Pada tahun 2017, empat diskusi meja bundar bersama para pemikir pembangunan terkemuka telah diadakan di London, Manila, Tokyo, dan Washington, DC. Para ahli tersebut membagikan wawasan mengenai peran ADB di Asia dan Pasifik pada tahun-tahun menuju 2030. Para ahli menekankan perlunya mengatasi kemiskinan dan ketimpangan, memerangi perubahan iklim, memperkuat kerja sama kawasan, mengintegrasikan teknologi dan solusi pengetahuan di berbagai proyek, melibatkan UMIC, dan mengkatalisasi pembiayaan sektor swasta. Beberapa ahli menganjurkan agar ADB tidak sekadar mengurusi pembangunan infrastruktur dan lebih berfokus pada sektor sosial. 
Para Ahli yang Diajak Berkonsultasi selama Pertemuan Meja Bundar Mengenai Strategi 2030

\begin{tabular}{|c|c|}
\hline Nama Ahli & Afiliasi \\
\hline Masood Ahmed & President, Center for Global Development, Washington, DC, Amerika Serikat \\
\hline Baroness Valerie Amos & Director, SOAS University of London, London, Inggris \\
\hline Shinji Asanuma & $\begin{array}{l}\text { Visiting Professor, Asian Public Policy Program, School of International and Public Policy, Hitotsubashi } \\
\text { University, Tokyo, Jepang }\end{array}$ \\
\hline Kaushik Basu & $\begin{array}{l}\text { Professor of Economics dan C. Marks Professor of International Studies, Cornell University, New York, Amerika } \\
\text { Serikat }\end{array}$ \\
\hline Rasheda Choudhury & Executive Director, Campaign for Popular Education, Bangladesh \\
\hline Lord Meghnad Desai & Chair, Advisory Board, Official Monetary and Financial Institutions Forum, London, Inggris \\
\hline Cinnamon Dornsife & $\begin{array}{l}\text { Senior Advisor, International Development Program dan Senior Fellow, Foreign Policy Institute, Johns Hopkins } \\
\text { University, Washington, DC, Amerika Serikat }\end{array}$ \\
\hline Nick Dyer & $\begin{array}{l}\text { Director General for Policy and Global Programmes, Department for International Development, London, } \\
\text { Inggris }\end{array}$ \\
\hline Gang Fan & $\begin{array}{l}\text { Director, National Economic Research Institute; dan Chair, China Reform Foundation, Beijing, Republik Rakyat } \\
\text { Tiongkok }\end{array}$ \\
\hline Nobuhiko Fuwa & Professor, Graduate School of Public Policy, University of Tokyo, Tokyo, Jepang \\
\hline Haihong Gao & $\begin{array}{l}\text { Professor dan Director, Research Center for International Finance, Institute of World Economics and Politics, } \\
\text { Chinese Academy of Social Sciences, Beijing, Republik Rakyat Tiongkok }\end{array}$ \\
\hline Nika Gilauri & Pendiri dan Managing Partner, Reformatics LLC; dan mantan Perdana Menteri, Georgia \\
\hline Maggie Gorman Vélez & Director, Policy and Evaluation, International Development Research Centre, Ottawa, Kanada \\
\hline C. Lawrence Greenwood, Jr. & President, Japan Society of Northern California, Amerika Serikat \\
\hline Margaret Huber & President, Canadian International Council, National Capital Branch, Ottawa, Kanada \\
\hline Yiping Huang & $\begin{array}{l}\text { Jin Guang Chair Professor of Economics and Deputy Dean, National School of Development; dan Director of } \\
\text { the Institute of Digital Finance, Peking University, Beijing, Republik Rakyat Tiongkok }\end{array}$ \\
\hline Jung Taik Hyun & President, Korea Institute for International Economic Policy, Sejong-Si, Republik Korea \\
\hline Shada Islam & Director of Europe and Geopolitics, Friends of Europe, Brussel, Belgia \\
\hline Shigeo Katsu & President, Nazarbayev University, Astana, Kazakhstan \\
\hline Homi Kharas & $\begin{array}{l}\text { Senior Fellow dan Deputy Director, Global Economy and Development Program, Brookings Institution, } \\
\text { Washington, DC, Amerika Serikat }\end{array}$ \\
\hline Carol Anne Kidu & Mantan Menteri Pembangunan Masyarakat dan Legislator, Papua Nugini \\
\hline Hisaki Kono & Associate Professor, Graduate School of Economics, Kyoto University, Kyoto, Jepang \\
\hline Rajiv Kumar & $\begin{array}{l}\text { Senior Fellow, Center for Policy Research, New Delhi, India; dan Chancellor, Gokhale Institute of Economics } \\
\text { and Politics, Maharashtra, India }\end{array}$ \\
\hline Tae-Shin Kwon & Vice Chair dan Chief Executive Officer, Federation of Korean Industries, Seoul, Republik Korea \\
\hline Johannes Linn & $\begin{array}{l}\text { Nonresident Senior Fellow, Global Economy and Development Program, Brookings Institution, Washington, } \\
\text { DC, Amerika Serikat }\end{array}$ \\
\hline Marc Mealy & Vice-President of Policy, US-ASEAN Business Council, Washington, DC, Amerika Serikat \\
\hline Victor Murinde & Professor, School of Finance and Management, SOAS University of London, London, Inggris \\
\hline Adoracion Navarro & $\begin{array}{l}\text { Undersecretary dan Head of Regional Development, National Economic and Development Authority, Pasig, } \\
\text { Filipina }\end{array}$ \\
\hline Carol Newman & Chair, Trinity International Development Initiative, Trinity College Dublin, Dublin, Irlandia \\
\hline Yumiko Noda & Partner, Head of Infrastructure and Public-Private Partnership, PwC Advisory LLC, Tokyo, Jepang \\
\hline Annmaree O’Keeffe & Nonresident Fellow, Lowy Institute, Sydney, Australia \\
\hline Izumi Ohno & Professor, National Graduate Institute for Policy Studies, Tokyo, Jepang \\
\hline Maaike Okano-Heijmans & Senior Research Fellow, Clingendael Institute, Den Haag, Belanda \\
\hline Zaw Oo & Executive Director, Centre for Economic and Social Development, Yangon, Myanmar \\
\hline
\end{tabular}




\begin{tabular}{|c|c|}
\hline Nama Ahli & Afiliasi \\
\hline Junko Otani & Professor, Graduate School of Human Sciences, Osaka University, Osaka, Jepang \\
\hline Keijiro Otsuka & Professor, Graduate School of Economics, Kobe University, Kobe, Jepang \\
\hline Mari Elka Pangestu & Guru Besar Ekonomi Internasional, Universitas Indonesia, Jakarta, Indonesia \\
\hline Matt Reed & Chief Executive Officer, Aga Khan Foundation UK, London, Inggris \\
\hline Dan Runde & $\begin{array}{l}\text { William A. Schreyer Chair dan Director of Project on Prosperity and Development, Center for Strategic and } \\
\text { International Studies, Washington, DC, Amerika Serikat }\end{array}$ \\
\hline Yuri Sato & $\begin{array}{l}\text { Executive Vice-President, Institute of Developing Economies, Japan External Trade Organization, Chiba, } \\
\text { Jepang }\end{array}$ \\
\hline Martin Seeger & Chief Executive Officer dan President, Lahmeyer International GmbH, Hesse, Jerman \\
\hline Yutaro Shintaku & Director dan Corporate Advisor, Terumo Corporation, Tokyo, Jepang \\
\hline Suzanne Siskel & Executive Vice-President dan Chief Operating Officer, Asia Foundation, San Francisco, Amerika Serikat \\
\hline Tetsushi Sonobe & $\begin{array}{l}\text { Vice-President; Chair of PhD Program Committee; Director of GRIPS Global Governance Program (G-cube); } \\
\text { Professor, National Graduate Institute for Policy Studies, Tokyo, Jepang }\end{array}$ \\
\hline Paola Subacchi & Research Director for International Economics, Chatham House, London, Inggris \\
\hline Akira Suehiro & Dean dan Professor, Faculty of International Social Sciences, Gakushuin University, Tokyo, Jepang \\
\hline Aya Suzuki & $\begin{array}{l}\text { Associate Professor, Department of International Studies, Graduate School of Frontier Sciences, University of } \\
\text { Tokyo, Chiba, Jepang }\end{array}$ \\
\hline Richard Teuten & $\begin{array}{l}\text { Head, International Financial Institutions Department, Department for International Development, London, } \\
\text { Inggris }\end{array}$ \\
\hline Yasuyuki Todo & $\begin{array}{l}\text { Professor, Graduate School of Economics, Faculty of Political Science and Economics, Waseda University, } \\
\text { Tokyo, Jepang }\end{array}$ \\
\hline Anote Tong & Mantan Presiden, Kiribati \\
\hline Kenichi Ueda & Associate Professor, Faculty of Economics, University of Tokyo, Tokyo, Jepang \\
\hline Kolone Vaai & Co-Managing Director dan Principal Consultant, KVAConsult Ltd, Apia, Samoa \\
\hline Chris Vermont & Chief Executive Officer, GuarantCo Management Company, London, Inggris \\
\hline Ulrich Volz & Head of Economics, SOAS University of London, London, Inggris \\
\hline Yoshihiro Watanabe & Professor, Graduate Institute for Entrepreneurial Studies, Niigata, Jepang \\
\hline Beatrice Weder di Mauro & $\begin{array}{l}\text { Professor of Economics dan Chair of Economic Policy and International Macroeconomics, University of Mainz, } \\
\text { Mainz, Jerman }\end{array}$ \\
\hline Olin Wethington & Nonresident Fellow, Atlantic Council, Washington, DC, Amerika Serikat \\
\hline Gerald Wright & Senior Fellow, Norman Paterson School of International Affairs, Carleton University, Ottawa, Kanada \\
\hline Daniel Zelikow & Head, International Public Sector Group, J.P. Morgan, Washington, DC, Amerika Serikat \\
\hline Weiying Zhang & $\begin{array}{l}\text { Sinar Mas Chair Professor of Economics, National School of Development, Peking University, Beijing, Republik } \\
\text { Rakyat Tiongkok }\end{array}$ \\
\hline
\end{tabular}

ASEAN = Asosiasi Negara-Negara Asia Tenggara, US = Amerika Serikat. Sumber: Asian Development Bank. 

www.adb.org/strategy2030

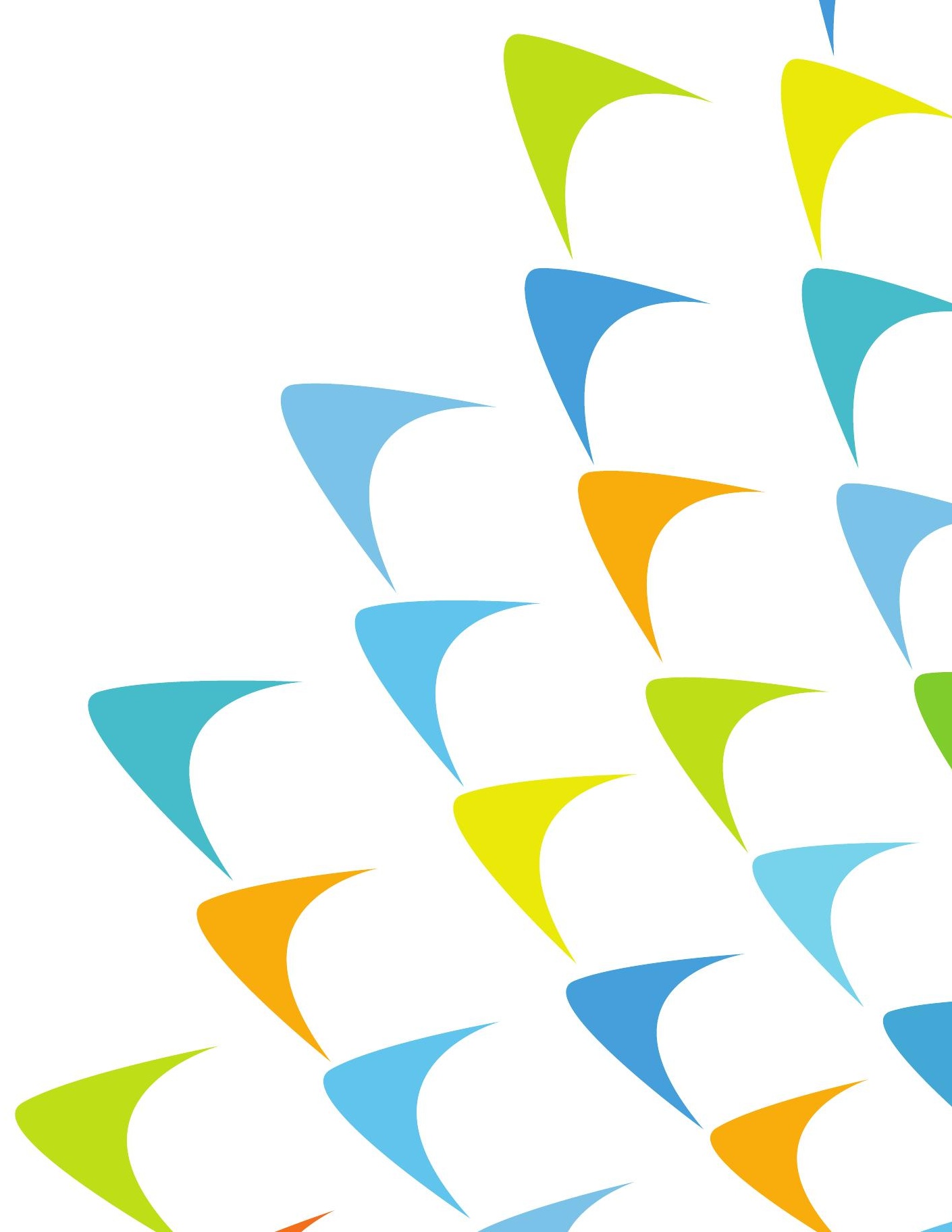




\section{Strategi 2030}

Mencapai Asia dan Pasifik yang Makmur, Inklusif, Tangguh, dan Berkelanjutan

Asia dan Pasifik telah mengalami kemajuan pesat dalam pengurangan kemiskinan dan pertumbuhan ekonomi dalam 50 tahun terakhir. Asian Development Bank (ADB) telah menjadi mitra penting dalam transformasi signifikan kawasan ini dan berkomitmen untuk terus melayani kawasan ini pada tahap pembangunan berikutnya. Strategi 2030 mengarahkan upaya ADB agar dapat efektif menanggapi perubahan kebutuhan di kawasan ini. Dengan Strategi 2030, ADB akan memperluas visinya untuk mencapai Asia dan Pasifik yang makmur, inklusif, tangguh, dan berkelanjutan, sambil melanjutkan upayanya memberantas kemiskinan ekstrem.

\section{Tentang Asian Development Bank}

ADB berkomitmen mencapai Asia dan Pasifik yang makmur, inklusif, tangguh, dan berkelanjutan, sambil melanjutkan upayanya memberantas kemiskinan ekstrem. Didirikan pada 1966, ADB dimiliki oleh 67 anggota-48 di antaranya berada di kawasan Asia dan Pasifik. Instrumen utama ADB untuk membantu negara berkembang anggotanya adalah dialog kebijakan, pinjaman, investasi saham, jaminan, hibah, dan bantuan teknis.

$\mathrm{ADB}$ 